\title{
ARTICLE
}

\section{ICT-finance-growth nexus: Empirical evidence from the Next-11 countries}

\author{
Rudra Prakash Pradhan ${ }^{a, *}$, Mak Arvin ${ }^{b}$, Mahendhiran Nair ${ }^{c}$, \\ Sara Bennett ${ }^{\mathrm{d}}$, Sahar Bahmani ${ }^{\mathrm{e}}$ \\ a Vinod Gupta School of Management, Indian Institute of Technology, Kharagpur 721302, India \\ b Department of Economics, Trent University, Peterborough, Ontario K9J 7B8, Canada \\ c School of Business, Monash University Malaysia, Jalan Lagoon Selatan 47500, Malaysia \\ d School of Business and Economics, Lynchburg College, Lynchburg, VA 24501, USA \\ e Department of Economics, University of Wisconsin at Parkside, Kenosha, WI 53144, USA
}

Received 3 October 2015; accepted 17 February 2016

Available online 22 March 2016

\section{JEL \\ CLASSIFICATION \\ L96; \\ 032; \\ 033; \\ 043}

\section{KEYWORDS}

ICT penetration;

Financial

development;

Economic growth;

Panel VAR;

Next-11 countries

\section{CÓDIGOS JEL}

L96;

032;

033;

043

\begin{abstract}
This study assesses the causal relationship between information and communication technology (ICT) penetration, financial development, and economic growth in Next-11 countries between 1961 and 2012. A panel vector auto-regressive (VAR) model is used to detect the direction of causality between ICT, financial sector development and economic growth for these countries. The results reveal that there is Granger-causality among the variables both in the short run and in the long run, although the exact nature of the results varies by the ICT penetration indicators for the sample countries. Empirical results from this study provide valuable insights on policies pertaining to ICT penetration, financial sector development and economic growth.

( 2016 Asociación Cuadernos de Economía. Published by Elsevier España, S.L.U. All rights reserved.
\end{abstract}

\footnotetext{
* Corresponding author.

E-mail address: rudrap@vgsom.iitkgp.ernet.in (R.P. Pradhan).
} 
PALABRAS CLAVE

Penetración de TIC; Desarrollo financiero;

Crecimiento

económico;

Panel VAR;

Próximos 11 países para detectar la dirección de causalidad entre las TIC, el desarrollo del sector financiero y el crecimiento económico para estos países. Los resultados revelan que existe una causalidad de Granger entre las variables tanto a corto como a medio plazo, si bien la naturaleza exacta de los hallazgos varía conforme a los indicadores de penetración de las TIC para los países de la muestra. Los resultados empíricos de este estudio suponen una valiosa perspectiva acerca de las políticas de penetración de las TIC, el desarrollo del sector financiero y el crecimiento económico.

(C) 2016 Asociación Cuadernos de Economía. Publicado por Elsevier España, S.L.U. Todos los derechos reservados.

\section{Introduction}

Over the past five decades, there has been rapid transformation of the global economy and many of the changes have been powered by the information and communication technology (ICT) revolution. ICT has become an integral part of the global economic architecture. ICT is regarded as a foundational condition for a knowledgeintensive economy, where the following can be achieved: (1) strengthening of collaboration between economic agents, thereby enabling firms to pursue open innovation (Fitjar and Rodríguez-Pose, 2013); (2) enhancing the innovative capacity of countries (Nair, 2011; Nair and Shariffadeen, 2009); (3) improving firm level productivity (Sadun and Farooqui, 2006; Forman et al., 2005; Entner, 2008); (4) providing easy access to a wide range of affordable products and services (Brown and Goolsbee, 2002; Baye et al., 2004; Tang et al., 2007); (5) opening new employment opportunities (Nair and Vaithilingam, 2012); (6) improving corporate and public sector governance (Kalam, 2003); and (7) providing marginalized communities access to information and resources for business development (Bhatnagar, 2000; Quibria et al., 2002).

Several studies have examined the impact of network externalities on economic growth and vice versa (see, for instance, Pradhan et al., 2014a). Additionally, the role of financial sector development has been extensively studied in the literature (see for example, King and Levine, 1993; Levine and Zervos, 1996; Levine et al., 2000; Ulgen, 2015). While the relationship between ICT on economic development has been well established, the literature that examines the dynamics between ICT penetration, financial sector development and economic growth is not well-developed. Hence, the primary objective of this paper is to examine the causal relationships between ICT penetration, financial sector development and economic growth using a panel vector auto-regressive (VAR) model for the Next-11 countries from 1961 to 2012. The results from the empirical analysis will have important policy implications pertaining to ICT penetration, financial sector development and pro-growth strategies.

The paper is structured as follows. Section 2 provides a theoretical basis, Section 3 offers a brief review of the literature. Section 4 provides the methodology used in this study, outlining the conceptual model, hypotheses and empirical methodology. Section 5 discusses the empirical results and
Section 6 provides the policy implications of the empirical results and concluding remarks.

\section{Theoretical basis}

Explaining the sources of economic growth ranks among the most significant topics that economists have examined. Romer (1986) initially started a set of theoretical and empirical analyses focusing on the endogeneity of the growth process as compared to Solow-type neoclassical growth models (Solow, 1956), which used an aggregate function approach and endogenous technical changes (Roller and Waverman, 2001). Numerous papers since then have attempted to disentangle the elements of a national economy that create the economic growth (see, for instance, Aghion and Howitt, 1998). The factors that determine economic growth can be grouped into three different types: the first group basically considers the accumulation of broad capital, including human capital and different types of physical capitals; the second group basically considers spillovers or external economies; and third group stresses industrial innovation as the engine of growth (Grossman and Helpman, 1994).

This paper examines the impact of ICT infrastructure and financial development on per capita economic growth. We cover some key economies (namely, the Next11 countries). Over recent decades, these policymakers in most of these countries have devoted considerable effort to developing their financial markets and ICT sectors to elevate their economic growth. Some of these efforts have included investment expansion, financial regulation, as well as improvements in the ICT infrastructure inter alia. Therefore, our study formally investigates whether the development of ICT and financial sectors can be causal factors of growth for these countries and whether they also cause each other. The balance of this section highlights the possible theoretical links between these variables.

ICT infrastructure is generally recognized as an important factor in determining economic growth. There are three reasons why this may be the case: (1) ICT are omnipresent in most business sectors, (2) ICT improves continuously and hence reduce costs for the users, and (3) ICT contributes to innovation and the development of the new products and processes (Andrianaivo and Kpodar, 2011). However, with the elevated role of ICT infrastructure, the issue of 
duality matters in the phases of economic growth (Dutta, 2001). That means there is the possibility of bidirectional causal relationships between ICT infrastructure and economic growth. Fig. C.1 in Appendix C summarizes the duality between ICT infrastructure and economic growth.

Analogously, financial development can be considered as an important factor in determining economic growth. The degree to which financial market activities are pervasive in a country is believed to be largely a function of five factors: (1) producing and processing information about possible investments and allocating capital based on these assessments, (2) monitoring individuals and firms and exerting corporate governance after allocating capital, (3) facilitating trade, (4) mobilizing and pooling savings, and (5) easing the exchange of goods, services, and financial instruments (Cihak et al., 2011). Again with the increasing importance of financial development, the issue of duality also matters in the phases of economic growth. That means there is possibility of bidirectional causality between financial development and economic growth (see Levine et al., 2000; King and Levine, 1993).

Finally, ICT infrastructure can be considered as an important factor for financial development. ICT generally allows expansion and access to financial services of the economy. It reduces transaction costs, especially the costs of running physical financial institution branches. Additionally, the increasing use of ICT services (especially mobile banking) has contributed to the emergence of branchless financial services, thereby improving financial inclusion in particular and financial development in general. In sum, ICT provides better information flows, particularly with reference to improving access to credit and deposit facilities, and can allow efficient allocation of credit, facilitate financial transfers, and boost financial development (Andrianaivo and Kpodar, 2011). Yet again with the increasing importance of ICT development, the issue of duality also matters here in the phases of financial development. That means there is possibility of bidirectional causality between ICT infrastructure and financial development (Pradhan et al., 2015).

\section{Literature review}

The literature on ICT-growth nexus and financial sector development-growth nexus are extensive. Our paper is directly related to these two stands of the literature.

There are four schools of thought in the ICT-growth literature. The first supports a supply-leading hypothesis (SLH), which argues that ICT penetration is a pre-condition for economic development. The proponents argue that, as economic agents become more connected to the information highway, they are able to extend their reach to obtain more information, knowledge, products, services and markets. This enables them to improve their productivity, innovative capacity and wealth creation opportunities. Among the empirical studies that show this line of argument include: Cieslik and Kaniewsk (2004), Chakraborty and Nandi (2003), and Mehmood and Siddiqui (2013).

The second school of thought advances the demandfollowing hypothesis (DFH), which suggests that countries that experience higher economic growth tend to increase spending on ICT development. Supporters of this hypothesis argue that as wealth levels in a country grow, economic agents tend to demand more sophisticated technology to improve their socioeconomic statuses. To meet the demand of the various stakeholders, governments invest a significant amount of resources to develop and upgrade the ICT infrastructure, support systems and regulatory environment. That is, economic development causes ICT penetration. Empirical studies that have shown the causal linkage from economic growth to ICT penetration include Beil et al. (2005), Lee et al. (2012), Pradhan et al. (2013a) and Shiu and Lam (2008a).

A third school of thought is the feedback hypothesis $(\mathrm{FBH})$, which argues that ICT can complement and can deepen the impact on economic growth and vice versa. Here, the proponents suggest that ICT improves economic productivity and economic growth opportunities. As the wealth of economic agents and countries increases, these countries tend to increase investments in ICT to continuously develop and upgrade not only the number of people using ICT, but also the quality of the ICT so as to enable firms to pursue economies of scale and scope and to move up the innovation value chain. The feedback between ICT development and economic growth has a reinforcing impact on each other, enabling the economy to gravitate to a higher stage of economic development. Empirical studies that supports the FBH include the following: Chakraborty and Nandi (2009, 2011), Wolde-Rufael (2007), and Zahra et al. (2008).

The final school of thought maintains that there is no causal link between ICT and economic growth, known as no linkage hypothesis (NLH). This hypothesis seems to be a minority in the literature. A study that has shown this result is Veeramacheneni et al. (2007).

A summary of the studies that have examined the causal link between ICT penetration and economic development is given in Table 1.

There has also been extensive work in the literature examining the causal relationship between financial sector development and economic growth. Similar to the ICTgrowth literature, there are four schools of thoughts on the causal relationship between financial sector development and economic growth. The first is the SLH, which suggests that financial sector development is important to facilitate economic growth. Schumpeter (1934) is one of the earliest works to postulate the impact of financial sector development on economic growth. Several other studies have also argued that financial sector development is a key catalyst for stimulating economic growth via the following channels: (1) reallocating resources from less productive sectors to more productive, growth-inducing sectors (Patrick, 1966); (2) providing valuable information and analysis of firms and markets to investors, hence reducing economic risks and uncertainties (Greenwood and Jovanovic, 1990); (3) increasing the ability of economic agents to accurately evaluate investment initiatives, mobilizing households savings for innovative activities and diversifying risks to enhance the innovation of intermediate goods (King and Levine, 1993); and (4) lowering costs of new investment, thus facilitating backward linkages with foreign firms and increasing rates of intermediate input and economic growth (Alfaro et al., 2004).

There are a number of studies that support DFH, which suggests that economic growth has a positive impact on 
Table 1 Summary of studies on the nexus between ICT penetration and economic growth.

\begin{tabular}{|c|c|c|c|c|}
\hline Study & Method & Study area & Study period & Finding \\
\hline Arvin and Pradhan (2014) & $\mathrm{b}$ & G-20 countries & $1998-2011$ & $\mathrm{FBH}^{1}$ \\
\hline Beil et al. (2005) & $\mathrm{a}$ & USA & 1947-1996 & $\mathrm{DFH}^{1}$ \\
\hline Chakraborty and Nandi (2003) & a & $12 \mathrm{ACs}$ & $1975-2000$ & $\mathrm{SLH}^{1}$ \\
\hline Chakraborty and Nandi (2009) & $a$ & $\mathrm{DCs}$ & $1980-2001$ & $\mathrm{FBH}^{1}$ \\
\hline Chakraborty and Nandi (2011) & $\mathrm{a}$ & 93 countries & $1985-2007$ & $\mathrm{FBH}^{1}$ \\
\hline Cieslik and Kaniewsk (2004) & a & Poland & 1989-1998 & $\mathrm{SLH}^{1}$ \\
\hline Cronin et al. (1991) & $a$ & USA & $1958-1988$ & $\mathrm{FBH}^{1}$ \\
\hline Dutta (2001) & $\mathrm{a}$ & $15 \mathrm{DCs} \& 15 \mathrm{ICs}$ & $1960-1993$ & $\mathrm{SLH}^{1}$ \\
\hline Lam and Shiu (2010) & $\mathrm{b}$ & 105 countries & $1980-2006$ & $\mathrm{FBH}^{1}$ \\
\hline Lee et al. (2012) & $a$ & 3 NACs & $1975-2009$ & $\mathrm{DFH}^{1}$ \\
\hline Mehmood and Siddiqui (2013) & $\mathrm{b}$ & $23 \mathrm{ACs}$ & $1990-2010$ & $\mathrm{SLH}^{1}$ \\
\hline Pradhan et al. (2013b) & $\mathrm{b}$ & 34 OECD countries & $1961-2011$ & $\mathrm{DFH}^{1}, \mathrm{FBH}^{1}$ \\
\hline Pradhan et al. (2014a) & a & G-20 countries & $1991-2012$ & $\mathrm{FBH}^{1}$ \\
\hline Pradhan et al. (2014b) & $\mathrm{a}$ & G-20 countries & $2001-2012$ & $\mathrm{SLH}^{1}, \mathrm{DFH}^{1}, \mathrm{FBH}^{1}$ \\
\hline Ramlan and Ahmed (2009) & a & Malaysia & $1965-2005$ & $\mathrm{NLH}^{1}$ \\
\hline Shiu and Lam (2008a) & $\mathrm{b}$ & China & $1978-2004$ & $\mathrm{SLH}^{1}, \mathrm{DFH}^{1}, \mathrm{NLH}^{1}$ \\
\hline Shiu and Lam (2008b) & $\mathrm{b}$ & 105 countries & $1980-2006$ & $\mathrm{FBH}^{1}$ \\
\hline Veeramacheneni et al. (2007) & $a$ & 10 LACs & $1975-2003$ & $\mathrm{NLH}^{1}$ \\
\hline Wolde-Rufael (2007) & a & USA & 1947-1996 & $\mathrm{FBH}^{1}$ \\
\hline Yoo and Kwak (2004) & $\mathrm{a}$ & Korea & $1965-1998$ & $\mathrm{SLH}^{1}$ \\
\hline Zahra et al. (2008) & a & 23 countries & $1990-2007$ & $\mathrm{FBH}^{1}$ \\
\hline
\end{tabular}

Note 1: $\mathrm{SLH}^{1}$ : supply-leading hypothesis: unidirectional causality is present from ICT to economic growth; $\mathrm{DFH}^{1}$ : demand-following hypothesis: unidirectional causality from economic growth to ICT is present; $\mathrm{FBH}^{1}$ : feedback hypothesis: bidirectional causality between ICT and economic growth is present; and $\mathrm{NLH}^{1}$ : neutrality hypothesis: no causality between ICT and economic growth is present.

Note 2: DCs: developing countries; ACs: Asian countries; CEE: Central and Eastern Europe; ICs: industrialised countries; NACs: Northeast Asian countries; LACs: Latin American countries.

Note 3: (a) Granger causality; and (b) Dynamic Panel Data Model.

financial development (Wolde-Rufael, 2009; Gries et al., 2009; Ang, 2008a,b). Accumulation of wealth due to robust economic growth will provide adequate resources to improve the technology, human capital, institutions, corporate governance, linkages between economic agents and innovation. These factors are important for improving the quality of the financial sector and increasing demand for more sophisticated financial systems, instruments and products. Studies that have shown the causal linkage between economic growth and financial sector development include Ang and McKibbin (2007), Liang and Teng (2006), Odhiambo (2008, 2010), Omri et al. (2015) and Panopoulou (2009). There have also been studies in the literature that support the FBH (Chow and Fung, 2011; Craigwell et al., 2001; Uddin et al., 2014; Wolde-Rufael, 2009) and the NLH (Mukhopadhyay et al., 2011; Pradhan et al., 2013c, 2014c).

A comprehensive summary of the studies that support the four hypotheses are given in Table 2.

The relationship between ICT penetration and financial sector development has received some attention in the literature. Improvements in ICT over the years have enabled financial institutions to obtain and disseminate information to various stakeholders, reducing information asymmetries and associated market failures (Morck et al., 2000). High speed communication networks have also enabled financial institutions to de-couple the 'space-time continuum', leading to the development of more efficient online financial, banking and brokerage platforms.
There have been very few studies that have examined the causal relations between ICT penetration and financial sector development. One of the studies that have examined this relationship is Shamim (2007), which shows that for a sample of 61 countries, 49 countries had causality from ICT connectivity to financial sector development. The study also shows that causality ran from financial sector development to ICT connectivity for the Netherlands, Nigeria, Spain, Switzerland, Thailand and the USA. In the case of Austria, China, France, Italy, Korea, and Malaysia the causal relations is bi-directional. A more recent study by Lechman and Marszk (2015) argues a strong relationship between ICT penetration and exchange traded funds for Japan, Mexico, the United States and Korea.

However, the trivariate-relationship between ICT penetration, financial development and economic growth is scarce in the development literature. To our knowledge, there are only two studies which have examined the above-mentioned relationship. Shamim (2007) used the Generalised Method of Moments (GMM) approach for a sample of 61 countries to show that connectivity variables deepen the impact of financial sector development on economic growth. Sassi and Goaied (2013) examine MENA countries using the GMM method and show that ICT development contributes positively to economic growth. On the other hand, they find that financial sector development has a negative impact on growth and that ICT development reinforces the role of financial sector development on economic growth in these countries. 
Table 2 Summary of studies on the nexus between financial development and economic growth.

\begin{tabular}{|c|c|c|c|c|}
\hline Study & Method & Study area & Study period & Finding \\
\hline Abu-Bader and Abu-Qarn (2008) & $\mathrm{b}$ & Egypt & $1960-2001$ & $\mathrm{SLH}^{2}$ \\
\hline Ang and McKibbin (2007) & d & Malaysia & $1960-2001$ & $\mathrm{DFH}^{2}$ \\
\hline Bojanic (2012) & $d$ & Bolivia & $1940-2010$ & $\mathrm{SLH}^{2}$ \\
\hline Boulila and Trabelsi (2004) & $a$ & Tunisia & $1962-1987$ & $\mathrm{SLH}^{2}$ \\
\hline Calderon and Liu (2003) & d & 109 countries & 1960-1994 & $\mathrm{SLH}^{2}$ \\
\hline Chaiechi (2012) & d & South Korea, Hong Kong, UK & $1990-2006$ & $\mathrm{SLH}^{2}$ \\
\hline Chow and Fung (2011) & $b$ & 69 countries & $1970-2004$ & $\mathrm{FBH}^{2}$ \\
\hline Craigwell et al. (2001) & $d$ & Barbados & 1974-1998 & $\mathrm{FBH}^{2}$ \\
\hline Dritsakis and Adamopoulos (2004) & $\mathrm{b}$ & Greece & $1960-2000$ & $\mathrm{FBH}^{2}$ \\
\hline Fase and Abma (2003) & $a$ & 9 Asian countries & $1978-1999$ & $\mathrm{SLH}^{2}$ \\
\hline Hsueh et al. (2013) & $a$ & Ten Asian countries & $1980-2007$ & $\mathrm{SLH}^{2}$ \\
\hline Jalil et al. (2010) & $\mathrm{b}$ & China & 1977-2006 & $\mathrm{SLH}^{2}$ \\
\hline Kar et al. (2011) & $d$ & 15 MENA countries & $1980-2007$ & $\mathrm{SLH}^{2}, \mathrm{DFH}^{2}$ \\
\hline Liang and Teng (2006) & $d$ & China & $1952-2001$ & $\mathrm{DFH}^{2}$ \\
\hline Menyah et al. (2014) & $\mathrm{b}$ & 21 African countries & $1965-2008$ & $\mathrm{SLH}^{2}, \mathrm{DFH}^{2}$ \\
\hline Mukhopadhyay et al. (2011) & $c$ & 7 Asian countries & 1979-2009 & $\mathrm{NLH}^{2}$ \\
\hline Naceur and Ghazouani (2007) & $d$ & MENA region & $1979-2003$ & $\mathrm{SLH}^{2}$ \\
\hline Odhiambo (2008) & $\mathrm{b}$ & Kenya & 1969-2005 & $\mathrm{DFH}^{2}$ \\
\hline Odhiambo (2010) & $d$ & South Africa & $1969-2006$ & $\mathrm{DFH}^{2}$ \\
\hline Omri et al. (2015) & $\mathrm{c}$ & MENA countries & 1990-2011 & $\mathrm{DFH}^{2}$ \\
\hline Panopoulou (2009) & $d$ & 5 countries & $1995-2007$ & $\mathrm{DFH}^{2}$ \\
\hline Pradhan et al. (2013c) & $\mathrm{a}$ & Asian countries & $1960-2011$ & $\mathrm{NLH}^{2}$ \\
\hline Pradhan et al. (2014c) & C & 25 ARF Countries & $1960-2012$ & $\mathrm{NLH}^{2}$ \\
\hline Pradhan et al. (2014d) & C & 35 Asian Countries & $1960-2011$ & $\mathrm{SLH}^{2}$ \\
\hline Uddin et al. (2014) & $\mathrm{b}$ & Bangladesh & $1975-2011$ & $\mathrm{FBH}^{2}$ \\
\hline Wolde-Rufael (2009) & $\mathrm{c}$ & Kenya & $1966-2005$ & $\mathrm{FBH}^{2}$ \\
\hline Wu et al. (2010) & d & European Union & $1976-2005$ & $\mathrm{SLH}^{2}$ \\
\hline
\end{tabular}

Note 1: $\mathrm{SLH}^{2}$ : supply-leading hypothesis: unidirectional causality is present from financial development to economic growth; $\mathrm{DFH}^{2}$ : demand-following hypothesis: unidirectional causality from economic growth to financial development is present; $\mathrm{FBH}^{2}$ : feedback hypothesis: bidirectional causality between financial development and economic growth is present; and NLH2: neutrality hypothesis: no causality between financial development and economic growth is present.

Note 2: (a) Bivariate Granger causality; (b) trivariate Granger causality; (c) quadvariate Granger causality; (d) multivariate Granger causality; MENA: Middle East and North Africa.

The above brief review of the literature highlights that the relationships between ICT penetration, financial development and economic growth have been mixed. Hence, there is a need for further analysis to understand the dynamics between these variables so that effective policy measures to ensure sustainable economic development can be introduced. In the light of the research gap identified in the literature, this paper examines the causal relationship between ICT penetration, financial development and economic growth for a panel of the Next-11 countries - a group of nations that have not been studied before in this literature.

\section{Methodology}

The contribution of our paper is three-fold. First, this study integrates ICT penetration with finance-growth nexus, which has not received much coverage in the literature. Second, we use a sample of 11 developed and developing countries, which have not been previously studied in the literature. We also utilize a long span time period (1961-2012).
Third, this study utilizes advanced panel cointegration and Granger causality tests to capture the dynamics between the three variables. This method, while common in the economics literature, has not gained much prominence in the information systems literature. In this section, the theoretical framework, hypothesis development, empirical model, description of the sample data and the empirical methodology are presented.

\subsection{Statement of the hypotheses}

In this paper, we examine the possible patterns of causal relationships between ICT penetration, ${ }^{1}$ financial development, and economic growth. The null hypotheses we will test are given below and summarized in Fig. 1:

\footnotetext{
1 ICT penetration (ICTPEN) is measured by telephone line penetration (TELLIN), mobile phone penetration (MOBILE), internet user penetration (INTUSE), internet server penetration (INTSER), fixed broadband penetration (FIXBRO) and a composite indicator of the ICT measure (ICTIND).
} 


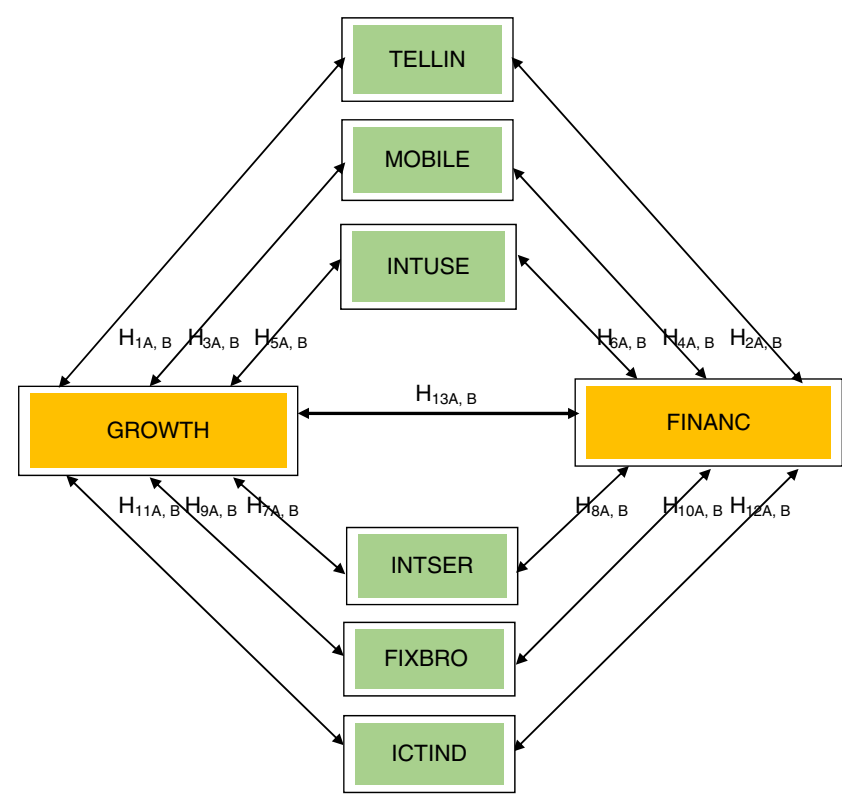

Figure 1 The relationship between ICT, financial development and economic growth. Note. GROWTH: per capita economic growth; FINANC: financial development; TELLIN; telephone lines penetration; MOBILE: mobile phone penetration; INTUSE: internet user penetration; INTSERV: internet server penetration; FIXBRO: fixed broadband penetration; and ICTIND: composite index of ICT penetration.

$\mathrm{H}_{1 \mathrm{~A}, \mathrm{~B}}$ : Telephone line penetration Granger-causes economic growth, and vice versa

$\mathrm{H}_{2 \mathrm{~A}, \mathrm{~B}}$ : Telephone line penetration Granger-causes financial development, and vice versa

$\mathrm{H}_{3 \mathrm{~A}, \mathrm{~B}}$ : Mobile phone penetration Granger-causes economic growth, and vice versa

$\mathrm{H}_{4 \mathrm{~A}, \mathrm{~B}}$ : Mobile phone penetration Granger-causes financial development, and vice versa

$\mathrm{H}_{5 \mathrm{~A}, \mathrm{~B}}$ : Internet user penetration Granger-causes economic growth, and vice versa

$\mathrm{H}_{6 \mathrm{~A}, \mathrm{~B}}$ : Internet user penetration Granger-causes financial development, and vice versa

$\mathrm{H}_{7 \mathrm{~A}, \mathrm{~B}}$ : Internet server penetration Granger-causes economic growth, and vice versa

$\mathrm{H}_{8 \mathrm{~A}, \mathrm{~B}}$ : Internet server penetration Granger-causes financial development, and vice versa

$\mathrm{H}_{9 \mathrm{~A}, \mathrm{~B}}$ : Broadband penetration Granger-causes economic growth, and vice versa

$\mathrm{H}_{10 \mathrm{~A}, \mathrm{~B}}$ : Broadband penetration Granger-causes financial development, and vice versa

$\mathrm{H}_{11 \mathrm{~A}, \mathrm{~B}}$ : ICT penetration Granger-causes economic growth, and vice versa

$\mathrm{H}_{12 \mathrm{~A}, \mathrm{~B}}$ : ICT penetration Granger-causes financial development, and vice versa

$\mathrm{H}_{13 \mathrm{~A}, \mathrm{~B}}$ : Economic growth Granger-causes financial development, and vice versa

\subsection{Model specification and data}

In order to examine the empirical relationships between ICT penetration, financialpagebreak development and economic growth, the following model is considered:

GROWTH $H_{i t}=B_{0 G R O W T H} F_{I N A N C}^{\beta_{1} G R O W T H i} I C T P E N_{i t}^{\beta_{2} G R O W T H i} e^{\varepsilon_{G R O W T H i t}}$

The logarithmic transformation of Eq. (1) is given by

$$
\begin{aligned}
\ln \left(\text { GROWTH }_{i t}\right)= & \beta_{0 G R O W T H}+\beta_{1 G R O W T H i} \ln \left(\text { FINANC }_{i t}\right) \\
& +\beta_{2 G R O W T H i} \ln \left(\text { ICTPEN }_{i t}\right)+\varepsilon_{G R O W T H i t}
\end{aligned}
$$

where $\beta_{0}=\ln \left(B_{0 G R O W T H}\right) ; i(=1,2, \ldots, N)$ represents a country in the sample; $t(=1,2, \ldots, T)$ denotes the time period for each country; and $\beta_{i}$ (for $i=1,2$ ) represents parameters of the model.

The task is to estimate the parameters in Eq. (2) and conduct some panel tests on the causal relationships between GROWTH, FINANC and ICTPEN. It is postulated that $\beta_{1 G R O W T H}>0$, which can justify that an increase in FINANC will likely cause an increase in GROWTH. Similarly, we expect $\beta_{2 G R O W T H}>0$, which can again justify that an increase in ICTPEN will likely cause an increase in GROWTH.

The variable GROWTH is the change in per capita gross domestic product, expressed in percentage. ICTPEN is information communication technology (ICT) penetration, which is measured by a composite index (variable: ICTIND) and five individual ICT penetration indicators: telephone landline penetration (variable: TELLIN), mobile phone penetration (variable: MOBILE), internet user penetration (variable: INTUSE), internet server penetration (variable: INTSER), and fixed broadband penetration (variable: FIXBRO). The final variable is FINANC which is a composite index of financial development and is the weighted average of nine financial development indicators: broad money supply (variable: BMONEY), claims on the private sector (variable: CLAIMS), domestic credit to the private sector (variable: DCPRIS), domestic credit provided by the banking sector (variable: DCBANK), domestic credit to the financial sector (variable: DCFINS), market capitalization (variable: SMACAP), traded stocks (variable: STMTRS), stock market turnover (STMTUR), and the number of listed companies in the stock market (variable: NLCOMP). Appendix A provides the detailed description of these variables (see Tables A.1 and A.2). The detailed descriptions about the formulation of the two composite indices (ICTIND and FINANC) are available in Appendix B.

We use the natural log of annual data on the Next11 countries, covering the period from 1961 to 2012. The countries in our sample are: Bangladesh, Egypt, Indonesia, Iran, South Korea, Mexico, Nigeria, Pakistan, Philippines, Turkey, and Vietnam. Since the ICT revolution over the years has occurred in several waves (from basic telephony, followed by internet, mobile phones and broadband technology), the dynamics between different ICT, financial development and economic growth are investigated for the following six different time periods: Case 1 (1961-2012) uses telephone line penetration; Case 2 (1991-2012) uses mobile phone penetration; Case 3 (1991-2012) uses internet user penetration; Case 4 (2001-2012) uses internet server penetration; Case 5 (2001-2012) uses fixed broadband penetration; Case 6 (2001-2012) uses the composite index of ICT penetration. 


\subsection{Panel unit root test}

Studies have shown that most of the economic and financial time series were found to be non-stationary (Engle and Granger, 2003). If two time series are non-stationary, regressing one series against the other will lead to spurious regression results (Granger and Newbold, 1974). Hence, before studying any empirical relationships, the stationarity properties of each time series should be ascertained. In this context, unit root test should be conducted to determine the order of integration of a series. The order of integration is determined by the number of times a non-stationary series is differenced until the series becomes stationary (Christopoulos and Tsionas, 2004).

In our study, the panel unit root test is deployed to estimate the degree (i.e., the order) of integration for GROWTH, ICTPEN and FINANC. While several panel unit root tests are available, we specifically use four panel unit root tests [the Levine-Lin-Chu test (LLC; Levine et al., 2002), the Im-Pesaran-Shin test (IPS; Im et al., 2003), the Maddala and Wu-Fisher Augmented Dickey Fuller (ADF) test, and the Maddala and Wu-Fisher Phillips and Perron (PP) test (Maddala and $\mathrm{Wu}, 1999)$ ] to check the stationarity of the variables. The LLC is a homogeneous panel unit root test, while IPS, $\mathrm{ADF}$ and PP are panel heterogeneous unit root tests. The tests employed in this study are widely used in the empirical literature and standard books on time series; hence the technical details of the tests are not included in this paper.

\subsection{Panel cointegration test}

Cointegration is a statistical concept that explains the long-run relationships between non-stationary variables. If the difference between two non-stationary series is itself stationary, then the two series are regarded as being cointegrated. If two or more series are cointegrated, then there exist long-run equilibrium relationships between these series. If the series are not cointegrated, then it is regarded that there is no long-run relationship between the series and the series may diverge from each other. In our study, the panel cointegration test is deployed to ascertain the longrun equilibrium relationships between GROWTH, ICTPEN and FINANC.

While several panel cointegration tests are available in the literature, we specifically use Pedroni's panel cointegration method (Pedroni, 2004) to determine the existence of cointegration among these three series. The technique starts with the following regression equation:

$$
\begin{aligned}
& \text { GROWTH }_{i t}=\beta_{\text {OGROWTHi }}+\beta_{1 G R O W T H i} t+\beta_{\text {2GROWTHi }} \text { FINANC }_{i t} \\
& +\beta_{3 \text { GROWTHIICTPEN }}+\varepsilon_{\text {GROWTHit }}
\end{aligned}
$$

where $\beta_{0 \text { OROWTHi }}$ is a member-specific intercept or fixedeffects parameter which is allowed to vary across individual cross-sectional units. $\beta_{1 \text { GROWTHi }}$ is a deterministic time trend specific to the individual countries in the panel. The slope coefficients $\left(\beta_{2 \text { GROWTHi }}\right.$ and $\left.\beta_{3 \text { GROWTHi }}\right)$ can vary from one country to another, allowing the cointegrating vectors to be heterogeneous across the panel members. Pedroni (2000)
Table 3 Testable hypotheses.

\begin{tabular}{ll}
\hline Causal flows & Testing restrictions \\
\hline FINANC $\Rightarrow$ GROWTH & $\gamma_{1 \text { GROWTHik }} \neq 0 ; \delta_{1 \text { GROWTHi }} \neq 0$ \\
GROWTH $\Rightarrow$ FINANC & $\beta_{\text {2GROWTHik }} \neq 0 ; \delta_{2 \text { GROWTHi }} \neq 0$ \\
ICTPEN $\Rightarrow$ GROWTH & $\lambda_{1 \text { GROWTHik }} \neq 0 ; \delta_{1 \text { GROWTHi }} \neq 0$ \\
GROWTH $\Rightarrow$ ICTPEN & $\beta_{3 \text { GROWTHik }} \neq 0 ; \delta_{3 \text { GROWTHi }} \neq 0$ \\
ICTPEN $\Rightarrow$ FINANC & $\lambda_{\text {2GROWTHik }} \neq 0 ; \delta_{2 \text { GROWTHi }} \neq 0$ \\
FINANC $\Rightarrow$ ICTPEN & $\gamma_{3 \text { GROWTHik }} \neq 0 ; \delta_{3 \text { GROWTHi }} \neq 0$
\end{tabular}

Note 1: GROWTH: per capita economic growth; FINANC: composite index of financial development; and ICTPEN: ICT penetration.

Note 2: ICT penetration is measured through five individual indicators (TELLIN, MOBILE, INTUSE, INTSER, FIXBRO) and the composite index (ICTIND).

Note 3: TELLIN; telephone lines penetration; MOBILE: mobile phone penetration; INTUSE: internet user penetration; INTSERV: internet server penetration; FIXBRO: fixed broadband penetration; and ICTIND: composite index of ICT penetration.

Note 4: The definitions of these variables are in Appendix A.

proposed seven different statistics for the cointegration test in the panel data setting. Since these statistics are again common in the literature, we do not provide the technical details of these statistics in this paper.

\subsection{FMOLS and DOLS estimation}

In the literature, there are a number of estimators for estimating a cointegration vector using panel data, including with- and between- group, such as ordinary least squares (OLS) estimators, fully modified OLS (FMOLS) estimators and the dynamic OLS (DOLS) estimators. Although simple OLS estimators of the cointegrated vectors are super-convergent, their distribution was found to be asymptotically biased and depends on nuisance parameters associated with the presence of serial correlation in the data (Pedroni, 2001). Many problems that exist in timeseries analysis may also arise in panel data analysis and tend to be more prevalent in the presence of heteroskedasticity (Kao and Chiang, 2000). Therefore, several other estimators have been proposed in the cointegrated literature. However, this study uses two panel cointegration estimators, namely the between-group fully modified OLS (FMOLS) ${ }^{2}$ and dynamic OLS (DOLS) ${ }^{3}$. Both FMOLS and DOLS were found to give consistent estimates of standard errors, which will render them to be robust for statistical inference. According to Kao and Chiang (2000), both FMOLS and DOLS estimators have normal limiting properties. In this study, we are interested in studying the nature of the relationships (positive or negative) between the variables. Since both FMOLS and DOLS

\footnotetext{
2 FMOLS is a non-parametric approach, which takes into account the possible correlation between the error term and the first differences of the regressors, as well as the presence of a constant term, to deal with corrections for serial correlation (Maeso-Fernandez et al., 2006; Pedroni, 2001).

${ }^{3}$ DOLS is a parametric approach, which adjusts the errors by augmenting the static regression with leads, lags, and contemporaneous values of the regressor in first differences (Mark and Sul, 2003; Kao and Chiang, 2000).
} 
Table 4 Results from panel unit root test.

\begin{tabular}{|c|c|c|c|c|c|c|c|c|c|}
\hline \multirow[t]{2}{*}{ Test statistics } & \multicolumn{3}{|c|}{ GROWTH } & \multicolumn{3}{|c|}{ FINANC } & \multicolumn{3}{|c|}{ ICTPEN } \\
\hline & NIT & INT & BIT & NIT & INT & BIT & NIT & INT & BIT \\
\hline \multicolumn{10}{|c|}{ Case 1: between GROWTH, FINANC, and TELLIN (1961-2012) } \\
\hline Levine-Lin-Chu (LLC) & $-14.7^{*}$ & $-8.90^{*}$ & $-6.82^{*}$ & $-7.91^{*}$ & $-2.80^{*}$ & $-2.26^{*}$ & $-11.8^{*}$ & $-6.51^{*}$ & $-4.64^{*}$ \\
\hline Maddala and Wu-Fisher ADF & $193.9^{*}$ & $130.4^{*}$ & $93.89^{*}$ & $90.50^{*}$ & $48.11^{*}$ & $37.52^{*}$ & $146.1^{*}$ & $96.87^{*}$ & $78.58^{*}$ \\
\hline Maddala and Wu-Fisher PP & $243.3^{*}$ & $1438^{*}$ & $1729^{*}$ & $156.9^{*}$ & $106.8^{*}$ & $87.12^{*}$ & $1244^{*}$ & $454^{*}$ & $366^{*}$ \\
\hline Inference & I [1] & $I[1]$ & $I[1]$ & & & & & & \\
\hline \multicolumn{10}{|c|}{ Case 2: between GROWTH, FINANC, and MOBILE (1991-2012) } \\
\hline Levine-Lin-Chu (LLC) & $-14.6^{*}$ & $-9.96^{*}$ & $-7.39^{*}$ & $-8.36^{*}$ & $-6.57^{*}$ & $-4.54^{*}$ & $-3.88^{*}$ & $-3.88^{*}$ & $-2.37^{*}$ \\
\hline Maddala and Wu-Fisher ADF & $192.9^{*}$ & 128.5 & $92.93^{*}$ & $96.50^{*}$ & $52.23^{*}$ & $78.58^{*}$ & $41.89^{*}$ & $48.42^{*}$ & $47.79^{*}$ \\
\hline Maddala and Wu-Fisher PP & $232.2^{*}$ & $1146^{*}$ & $1148^{*}$ & $141.8^{*}$ & $96.50^{*}$ & $91.72^{*}$ & $55.67^{*}$ & $61.86^{*}$ & $56.87^{*}$ \\
\hline \multicolumn{10}{|c|}{ Case 3: between GROWTH, FINANC, and INTUSE (1991-2012) } \\
\hline Levine-Lin-Chu (LLC) & $-13.5^{*}$ & $-8.68^{*}$ & $-6.23^{*}$ & $-7.08^{*}$ & $-5.89^{*}$ & $-4.37^{*}$ & $-6.65^{*}$ & $-4.53^{*}$ & $-3.36^{*}$ \\
\hline Maddala and Wu-Fisher ADF & $170.1^{*}$ & $107.2^{*}$ & $74.99^{*}$ & $81.30^{*}$ & $47.29^{*}$ & $46.49^{*}$ & $76.3^{*}$ & $46.2^{*}$ & $38.54^{*}$ \\
\hline Maddala and Wu-Fisher PP & $192.9^{*}$ & $914.6^{*}$ & $612.6^{*}$ & $142.0^{*}$ & $102.4^{*}$ & $101.6^{*}$ & $120.1^{*}$ & $105.1^{*}$ & $92.5^{*}$ \\
\hline \multicolumn{10}{|c|}{ Case 4: between GROWTH, FINANC, and INTSER (2001-2012) } \\
\hline Levine-Lin-Chu (LLC) & $-10.2^{*}$ & $-8.89^{*}$ & $-8.82^{*}$ & $-5.50^{*}$ & -4.26 & $-3.41^{*}$ & $-6.52^{*}$ & $-6.50^{*}$ & $-4.06^{*}$ \\
\hline Maddala and Wu-Fisher ADF & $106.3^{*}$ & $59.79^{*}$ & $37.25^{*}$ & $55.9^{*}$ & $41.61^{*}$ & $32.34^{*}$ & $61.73^{*}$ & $45.44^{*}$ & $50.93^{*}$ \\
\hline Maddala and Wu-Fisher PP & $169.2^{*}$ & $130.9^{*}$ & $97.06^{*}$ & $88.6^{*}$ & $90.79^{*}$ & $80.79^{*}$ & $64.1^{*}$ & $53.29^{*}$ & $41.19^{*}$ \\
\hline \multicolumn{10}{|c|}{ Case 5: between GROWTH, FINANC, and FIXBRO (2001-2012) } \\
\hline Levine-Lin-Chu (LLC) & $-9.04^{*}$ & $-4.44^{*}$ & $-3.96^{*}$ & $-4.43^{*}$ & $-3.29^{*}$ & $-2.70^{* *}$ & $-20.8^{*}$ & $-14.0^{*}$ & $-13.3^{*}$ \\
\hline Maddala and Wu-Fisher ADF & $81.7^{*}$ & $46.96^{*}$ & $28.87^{* *}$ & $40.6^{*}$ & $29.0^{* *}$ & $24.2^{* *}$ & $92.8^{*}$ & $73.8^{*}$ & $57.2^{*}$ \\
\hline Maddala and Wu-Fisher PP & $141.8^{*}$ & $127.3^{*}$ & $106.0^{*}$ & $87.8^{*}$ & $78.9^{*}$ & $72.3^{*}$ & $63.9^{*}$ & $53.8^{*}$ & $47.2^{*}$ \\
\hline \multicolumn{10}{|c|}{ Case 6: between GROWTH, FINANC, and ICTIND (2001-2012) } \\
\hline Levine-Lin-Chu (LLC) & $-7.36^{*}$ & $-5.87^{*}$ & $-3.92^{*}$ & $-5.12^{*}$ & $-4.65^{*}$ & $-2.29^{* *}$ & $-7.63^{*}$ & $-3.26^{*}$ & $-2.40^{*}$ \\
\hline Maddala and Wu-Fisher ADF & $66.7^{*}$ & $30.72^{* *}$ & $25.9^{* * *}$ & $46.3^{*}$ & $38.55^{*}$ & $28.32^{* *}$ & $61.38^{*}$ & $32.14^{*}$ & $23.28^{*+1}$ \\
\hline Maddala and Wu-Fisher PP & $131.4^{*}$ & $91.09^{*}$ & $76.67^{*}$ & $76.28^{*}$ & $57.79^{*}$ & $54.71^{*}$ & $103.1^{*}$ & $80.68^{*}$ & $69.4^{*}$ \\
\hline
\end{tabular}

Note 1: GROWTH: per capita economic growth; FINANC: financial development; TELLIN; telephone lines penetration; MOBILE: mobile phone penetration; INTUSE: internet user penetration; INTSERV: internet server penetration; FIXBRO: fixed broadband penetration; ICTIND: composite index of ICT penetration; ADF: Augmented Dickey Fuller; and PP: Phillips and Perron.

Note 2: The figures are reported here at the first difference level.

Note 3: NIT is no trend and intercept, INT is intercept only, and BIT is both intercept and trend.

* Statistical level of significance at $1 \%$ level

** Statistical level of significance at $5 \%$ level.

estimators are very common and readily available in most of the financial time series econometrics books, the technical details of these estimators are not included in this paper.

\subsection{VECM estimation}

Engle and Granger (1987) demonstrate that when variables are cointegrated, an error-correction model necessarily describes the data-generating process. Therefore, on the basis of the unit root and cointegration test results above, we use vector error-correction models (VECMs) to determine the causal relationships between our three sets of variables. In other words, we seek to determine which variable causes the other in the presence of the third variable. We are able to determine this causal link for both the short run and the long run. Following the methodological approach proposed by Canning and Pedroni (2008) and Holtz-Eakin et al. (1988), the panel Granger causality test is employed to ascertain the direction of causality between the three variables. The following econometric model is used:

$$
\begin{aligned}
{\left[\begin{array}{l}
\Delta \ln \text { GROWTH }_{i t} \\
\Delta \ln \text { FINANC }_{i t} \\
\Delta \ln \text { ICTPEN }_{i t}
\end{array}\right]=} & {\left[\begin{array}{l}
\beta_{1 G R O W T H j} \\
\beta_{2 G R O W T H j} \\
\beta_{3 G R O W T H j}
\end{array}\right]+\sum_{k=1}^{p}\left[\begin{array}{l}
\beta_{1 G R O W T H i k}(L) \gamma_{1 G R O W T H i k}(L) \lambda_{1 G R O W T H i k}(L) \\
\beta_{2 G R O W T H i k}(L) \gamma_{2 G R O W T H i k}(L) \lambda_{2 G R O W T H i k}(L) \\
\beta_{3 G R O W T H i k}(L) \gamma_{3 G R O W T H i k}(L) \lambda_{3 G R O W T H i k}(L)
\end{array}\right]\left[\begin{array}{l}
\Delta \ln G_{\text {GROWTH }} \text { it-k } \\
\Delta \ln \text { FINANC }_{i t-k} \\
\Delta \ln \text { ICTPEN }_{i t-k}
\end{array}\right] } \\
& +\left[\begin{array}{l}
\delta_{1 G R O W T H i} E C T_{1 G R O W T H i t-1} \\
\delta_{2 G R O W T H i} E C T_{2 G R O W T H i t-1} \\
\delta_{3 G R O W T H i} E C T_{3 G R O W T H i t-1}
\end{array}\right]+\left[\begin{array}{l}
\psi_{1 G R O W T H i t} \\
\psi_{2 G R O W T H i t} \\
\psi_{3 G R O W T H i t}
\end{array}\right]
\end{aligned}
$$


Table 5 Results of Pedroni panel cointegration test.

\begin{tabular}{|c|c|c|c|c|c|c|}
\hline Test statistics & & & & & $\begin{array}{r}n \\
\text { Interc }\end{array}$ & \\
\hline Case 1: between GROW & $A N C$, and & $961-20$ & & & & \\
\hline Panel $v$-statistics & -0.50 & {$[0.69]$} & -1.36 & {$[0.91]$} & -3.54 & {$[0.99]$} \\
\hline Panel $\rho$-statistics & $-5.96^{*}$ & {$[0.00]$} & $-5.55^{*}$ & {$[0.00]$} & $-3.48^{*}$ & {$[0.00]$} \\
\hline Panel PP-statistics & $-7.31^{*}$ & {$[0.00]$} & $-8.86^{*}$ & {$[0.00]$} & $-8.97^{*}$ & {$[0.00]$} \\
\hline Panel ADF-statistics & $-4.17^{*}$ & {$[0.00]$} & $-4.63^{*}$ & {$[0.00]$} & $-3.88^{*}$ & {$[0.00]$} \\
\hline Group $\rho$-statistics & $-3.68^{*}$ & {$[0.00]$} & $-2.78^{*}$ & {$[0.00]$} & -0.99 & {$[0.16]$} \\
\hline Group PP-statistics & $-8.25^{*}$ & {$[0.00]$} & $-10.6^{*}$ & {$[0.00]$} & $-11.2^{*}$ & {$[0.00]$} \\
\hline $\begin{array}{l}\text { Group ADF-statistics } \\
\text { Inference }\end{array}$ & $\begin{array}{l}-3.58^{*} \\
\text { Cointeg }\end{array}$ & {$[0.00]$} & $-4.81^{*}$ & {$[0.00]$} & $-3.73^{*}$ & [0.00] \\
\hline Case 2: between GROW & ANC, and & $1991-20$ & & & & \\
\hline Panel $v$-statistics & $2.07^{* *}$ & {$[0.02]$} & -1.13 & {$[0.12]$} & -1.49 & [0.93] \\
\hline Panel $\rho$-statistics & $-6.14^{*}$ & {$[0.00]$} & $-5.37^{*}$ & {$[0.00]$} & -3.24 & {$[0.00]$} \\
\hline Panel PP-statistics & $-7.56^{*}$ & {$[0.00]$} & $-8.67^{*}$ & {$[0.00]$} & $-9.37^{*}$ & {$[0.00]$} \\
\hline Panel ADF-statistics & $-4.57^{*}$ & {$[0.00]$} & $-4.53^{*}$ & {$[0.00]$} & $-4.70^{*}$ & {$[0.00]$} \\
\hline Group $\rho$-statistics & $-4.04^{*}$ & {$[0.00]$} & $-2.18^{*}$ & {$[0.00]$} & -0.27 & [0.39] \\
\hline Group PP-statistics & $-9.24^{*}$ & {$[0.00]$} & $-11.6^{*}$ & {$[0.00]$} & $-14.2^{*}$ & [0.00] \\
\hline $\begin{array}{l}\text { Group ADF-statistics } \\
\text { Inference }\end{array}$ & $\begin{array}{l}-5.62^{*} \\
\text { Cointeg }\end{array}$ & {$[0.00]$} & $-5.26^{*}$ & {$[0.00]$} & $-4.52^{*}$ & {$[0.00]$} \\
\hline Case 3: between GROW & $A N C$, and & $991-20$ & & & & \\
\hline Panel $v$-statistics & -0.62 & {$[0.27]$} & -0.43 & {$[0.66]$} & -2.59 & [0.99] \\
\hline Panel $\rho$-statistics & $-4.77^{*}$ & {$[0.00]$} & $-3.94^{*}$ & {$[0.00]$} & $-3.43^{*}$ & {$[0.00]$} \\
\hline Panel PP-statistics & $-6.98^{*}$ & {$[0.00]$} & $-7.27^{*}$ & {$[0.00]$} & $-10.5^{*}$ & {$[0.00]$} \\
\hline Panel ADF-statistics & $-4.43^{*}$ & {$[0.00]$} & -3.74 & {$[0.00]$} & $-5.24^{*}$ & {$[0.00]$} \\
\hline Group $\rho$-statistics & $-2.25^{*}$ & {$[0.00]$} & -0.90 & {$[0.18]$} & -0.97 & [0.83] \\
\hline Group PP-statistics & $-7.41^{*}$ & {$[0.00]$} & $-8.90^{*}$ & {$[0.00]$} & $-11.6^{*}$ & {$[0.00]$} \\
\hline $\begin{array}{l}\text { Group ADF-statistics } \\
\text { Inference }\end{array}$ & $\begin{array}{l}-5.17^{*} \\
\text { Cointeg }\end{array}$ & {$[0.00]$} & $-4.01^{*}$ & {$[0.00]$} & $-3.65^{*}$ & {$[0.00]$} \\
\hline Case 4: between GROW & $A N C$, and & $001-20$ & & & & \\
\hline Panel $v$-statistics & -0.46 & {$[0.67]$} & -1.21 & {$[0.91]$} & -3.24 & [0.99] \\
\hline Panel $\rho$-statistics & $-2.88^{*}$ & {$[0.01]$} & 0.14 & {$[0.56]$} & 1.75 & [0.96] \\
\hline Panel PP-statistics & $-4.34^{*}$ & {$[0.00]$} & $-4.32^{*}$ & {$[0.00]$} & $-2.87^{*}$ & {$[0.00]$} \\
\hline Panel ADF-statistics & $-2.62^{*}$ & {$[0.00]$} & $-3.26^{*}$ & {$[0.00]$} & -0.97 & {$[0.16]$} \\
\hline Group $\rho$-statistics & 0.48 & [0.69] & 1.80 & [0.96] & 3.03 & [0.96] \\
\hline Group PP-statistics & $-6.25^{*}$ & {$[0.00]$} & $-7.00^{*}$ & {$[0.00]$} & $-7.64^{*}$ & {$[0.00]$} \\
\hline $\begin{array}{l}\text { Group ADF-statistics } \\
\text { Inference }\end{array}$ & $\begin{array}{l}-3.95^{*} \\
\text { Cointeg }\end{array}$ & {$[0.00]$} & $-3.07^{*}$ & {$[0.00]$} & $-1.59^{* *}$ & [0.05] \\
\hline Case 5: between GROW & $A N C$, and & not & & & & \\
\hline Panel $v$-statistics & -0.61 & {$[0.72]$} & -1.33 & {$[0.90]$} & -3.04 & [0.99] \\
\hline Panel $\rho$-statistics & $-2.58^{*}$ & {$[0.00]$} & $-1.94^{* *}$ & {$[0.03]$} & 0.89 & {$[0.81]$} \\
\hline Panel PP-statistics & $-4.78^{*}$ & {$[0.00]$} & 6.01 & {$[0.00]$} & $-6.01^{*}$ & {$[0.00]$} \\
\hline Panel ADF-statistics & -1.94 & {$[0.02]$} & $-1.79^{* *}$ & {$[0.05]$} & $-2.71^{*}$ & {$[0.00]$} \\
\hline Group $\rho$-statistics & 0.13 & {$[0.55]$} & 0.47 & {$[0.68]$} & 2.02 & {$[0.97]$} \\
\hline Group PP-statistics & $-4.86^{*}$ & {$[0.00]$} & $-8.20^{*}$ & {$[0.00]$} & $-13.6^{*}$ & {$[0.00]$} \\
\hline $\begin{array}{l}\text { Group ADF-statistics } \\
\text { Inference }\end{array}$ & $\begin{array}{l}-2.42^{*} \\
\text { Cointeg }\end{array}$ & {$[0.00]$} & $-2.27^{*}$ & {$[0.01]$} & $-3.64^{*}$ & {$[0.00]$} \\
\hline Case 6: between GROW & $A N C$, and & $001-201$ & & & & \\
\hline Panel $v$-statistics & -0.87 & {$[0.80]$} & -1.68 & {$[0.95]$} & -3.40 & [0.99] \\
\hline Panel $\rho$-statistics & -1.08 & {$[0.14]$} & 0.61 & {$[0.73]$} & 2.42 & [0.99] \\
\hline Panel PP-statistics & $-3.12^{*}$ & {$[0.00]$} & $-2.53^{*}$ & {$[0.01]$} & $-1.84^{* *}$ & [0.03] \\
\hline Panel ADF-statistics & $-2.14^{*}$ & {$[0.00]$} & -1.35 & {$[0.09]$} & -0.66 & [0.25] \\
\hline Group $\rho$-statistics & 1.18 & {$[0.88]$} & 1.99 & {$[0.98]$} & 2.73 & [0.99] \\
\hline Group PP-statistics & $-4.71^{*}$ & {$[0.00]$} & $-6.17^{*}$ & {$[0.00]$} & $-8.92^{*}$ & {$[0.00]$} \\
\hline $\begin{array}{l}\text { Group ADF-statistics } \\
\text { Inference }\end{array}$ & $\begin{array}{l}-3.90^{*} \\
\text { Cointeg }\end{array}$ & {$[0.00]$} & $-2.28^{* *}$ & {$[0.05]$} & -2.20 & [0.01] \\
\hline
\end{tabular}

Note 1: GROWTH: per capita economic growth; FINANC: financial development; TELLIN; telephone lines penetration; MOBILE: mobile phone penetration; INTUSE: internet user penetration; INTSERV: internet server penetration; FIXBRO: fixed broadband penetration; and ICTIND: composite index of ICT penetration.

Note 2: Figures in square brackets are probability levels indicating significance.

" Statistical level of significance at $1 \%$ level.

** Statistical level of significance at $5 \%$ level. 
Table 6 Panel FMOLS and DOLS results.

\begin{tabular}{|c|c|c|c|c|c|}
\hline \multirow[t]{3}{*}{ Dependent variable } & \multirow[t]{3}{*}{ Independent variables } & \multicolumn{4}{|c|}{ Method } \\
\hline & & \multicolumn{2}{|c|}{ FMOLS } & \multicolumn{2}{|c|}{ DOLS } \\
\hline & & Coefficients & $t$-Statistic & Coefficients & $t$-Statistic \\
\hline \multicolumn{6}{|c|}{ Case 1: between GROWTH, FINANC, and TELLIN (1961-2012) } \\
\hline \multirow{2}{*}{ GROWTH } & FINANC & 0.16 & $3.37^{*}$ & 0.35 & $4.24^{*}$ \\
\hline & TELLIN & 0.10 & $2.58^{*}$ & 0.15 & $3.24^{*}$ \\
\hline \multicolumn{6}{|c|}{ Case 2: between GROWTH, FINANC, and MOBILE (1991-2012) } \\
\hline \multirow{2}{*}{ GROWTH } & FINANC & 0.15 & $4.85^{*}$ & 0.22 & $3.36^{*}$ \\
\hline & MOBILE & 0.04 & $4.11^{*}$ & 0.03 & $2.89^{*}$ \\
\hline \multicolumn{6}{|c|}{ Case 3: between GROWTH, FINANC, and INTUSE (1991-2012) } \\
\hline \multirow{2}{*}{ GROWTH } & FINANC & 1.12 & $2.52^{*}$ & 0.40 & $2.87^{*}$ \\
\hline & INTUSE & 0.03 & $6.60^{*}$ & 0.01 & $2.61^{*}$ \\
\hline \multicolumn{6}{|c|}{ Case 4: between GROWTH, FINANC, and INTSER (2001-2012) } \\
\hline \multirow{2}{*}{ GROWTH } & FINANC & 1.13 & $6.87^{*}$ & 1.11 & $2.53^{*}$ \\
\hline & INTSER & 0.05 & $2.88^{*}$ & 0.04 & $2.17^{*}$ \\
\hline \multicolumn{6}{|c|}{ Case 5: between GROWTH, FINANC, and FIXBRO (2001-2012) } \\
\hline \multirow{2}{*}{ GROWTH } & FINANC & 1.31 & $3.76^{*}$ & 1.13 & $7.76^{*}$ \\
\hline & FIXBRO & 0.02 & $3.65^{*}$ & 0.04 & $3.18^{*}$ \\
\hline \multicolumn{6}{|c|}{ Case 6: between GROWTH, FINANC, and ICTIND (2001-2012) } \\
\hline \multirow{2}{*}{ GROWTH } & FINANC & 1.21 & $4.37^{*}$ & 1.35 & $9.78^{*}$ \\
\hline & ICTIND & 0.03 & $3.89^{*}$ & 0.04 & $3.96^{*}$ \\
\hline
\end{tabular}

Note. GROWTH: per capita economic growth; FINANC: financial development; TELLIN; telephone lines penetration; MOBILE: mobile phone penetration; INTUSE: internet user penetration; INTSERV: internet server penetration; FIXBRO: fixed broadband penetration; and ICTIND: composite index of ICT penetration.

* Rejection of the null hypothesis at $1 \%$ level.

where $p$ is the lag lengths for the differenced variables; $\Delta$ is the first difference filter $(I-L) ; i=1, \ldots, N ; t=1, \ldots, T$; and, $\varepsilon_{j}(j=1,2,3)$ are independently and normally distributed random variables for all $i$ and $t$, with zero means and finite heterogeneous variances $\left(\sigma_{i}^{2}\right)$.

The ECTs are error-correction terms derived from the cointegrating equations. The ECTs represent long-run dynamics, while differenced variables represent shortrun dynamics between the variables. We look for both short-run and long-run Granger causal relationships. Shortrun Granger causal relationships are measured using $F$-statistics and the significance of the lagged changes in the independent variables, whereas long-run Granger causal relationships are measured using the significance of the $t$ test of the lagged ECTs. The coefficient $\delta_{s G R O W T H}$ (for $s=1,2$, 3) measures the speed of adjustment to long-term equilibrium. The higher the coefficient, the faster the adjustment to the long-run equilibrium is. Based on Eq. (4), Table 3 summarizes the testable hypotheses on causal relationships among ICT penetration, financial development, and economic growth.

\section{Empirical findings}

We begin with a discussion of the integration and cointegration properties of the variables. The estimated results confirm that the variables are integrated of order one (see Table 4) and are cointegrated (see Table 5). This is true for all the cases that we consider (Cases 1-6). The combined results of both integration and cointegration indicate the presence of a long-run equilibrium relationship between financial development, ICT penetration, and economic growth.

Having confirmed the existence of cointegration, the next step is to estimate the associated long-run cointegration parameters by FMOLS and DOLS procedures. The estimated results are presented in Table 6 . The results indicate that economic growth is significantly influenced by both financial development and ICT penetration. This is again true for all six cases (Cases 1-6 as shown in Table 6).

After confirming cointegration, the next step is to check the direction of causality between these three variables. The panel Granger causality test, based on the panel vector error-correction model, is used for this purpose. Table 7 presents the Granger causal relationships among the variables based on the estimation of Eq. (4). These results are summarized below.

\subsection{Long-run Granger causality results}

From Table 7, when $\triangle$ GROWTH serves as the dependent variable, the lagged error-correction term is statistically significant at the $1 \%$ level. This implies that economic 
Table 7 Panel Granger causality test results.

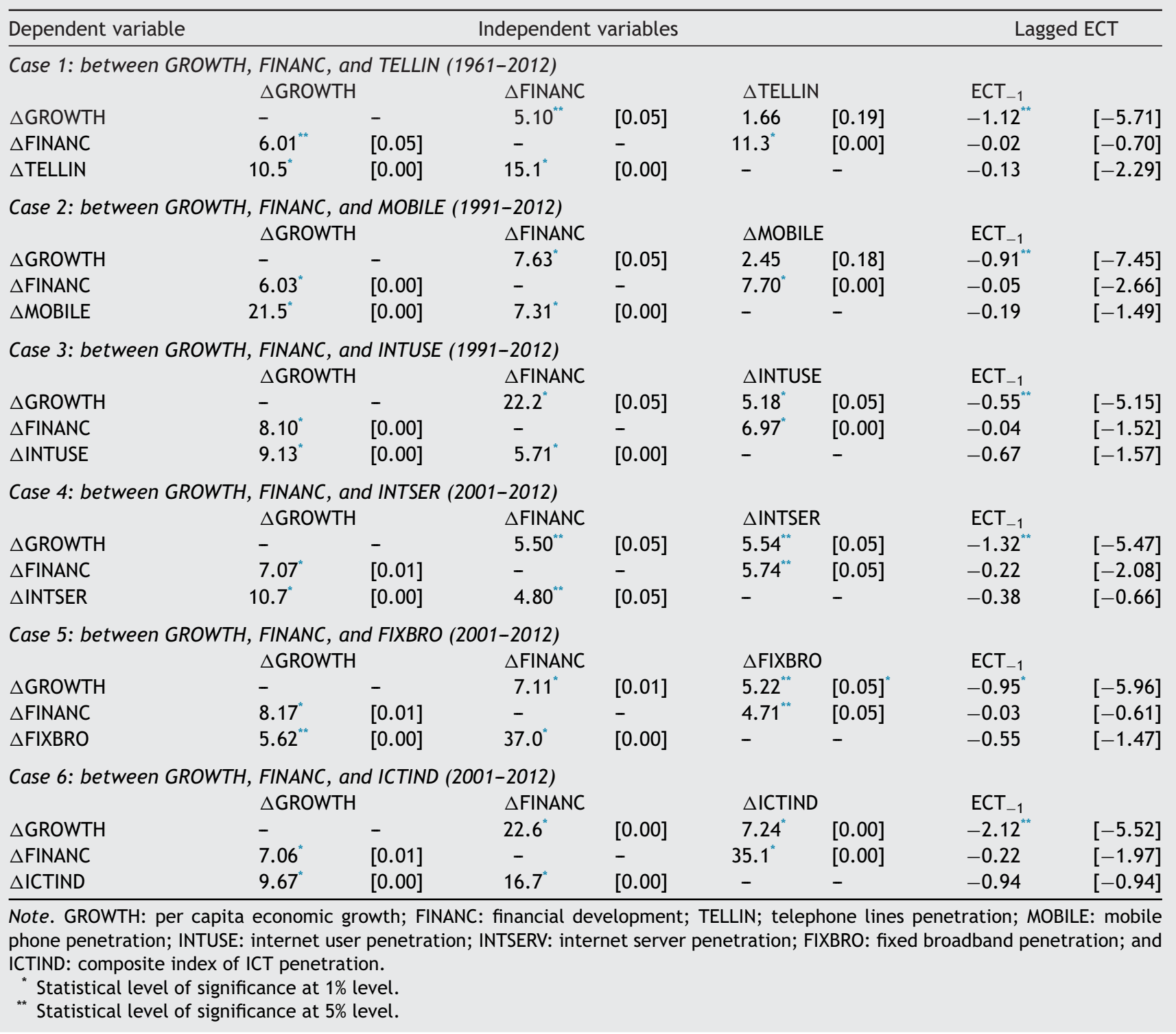

growth tends to converge to its long-run equilibrium path in response to changes in its regressors, namely ICT penetration and financial development.

The estimated lagged ECT (in all situations: Cases 1-6) carries a negative sign. This implies that the change in the level of economic growth $(\triangle \mathrm{GROWTH})$ does in fact rapidly respond to any deviation in the long-run equilibrium (or short-run disequilibrium) for the $t-1$ period. In other words, the effect of an instantaneous shock to ICT penetration and financial development on economic growth will be completely adjusted in the long run.

The speeds of adjustment between GROWTH, FINANC and ICTPEN in these six cases vary between $0.55 \%$ and $2.12 \%$. However, when we considered $\triangle$ FINANC or $\triangle$ ICTPEN as the dependent variable, the ECTs are not statistically significant. The statistical insignificance of the ECTs suggests that economic growth (or FINANC or ICTPEN) does not respond to deviations from long-run equilibrium.

\subsection{Short-run Granger causality results}

\subsubsection{Dynamics between financial development and economic growth}

We find evidence of bidirectional causality between financial development and economic growth for all the cases (see Table 8, Cases 1-6). This supports the feedback hypothesis of finance-growth nexus and is consistent with the findings of Chow and Fung (2011), Dritsakis and Adamopoulos (2004), Pradhan et al. (2014a,b), Uddin et al. (2014), and WoldeRufael (2009) for the various regions and countries that they study.

\subsubsection{Dynamics between ICT penetration and economic growth}

Here, we find evidence of both bidirectional and unidirectional causality between ICT penetration and economic growth. The bidirectional causality is visible between 
Table 8 The summary of short-run inference between ICT penetration, financial development and economic growth in the Next-11 countries.

\begin{tabular}{|c|c|c|c|}
\hline Causal relationships tested in the model & FINANC vs. GROWTH & ICTPEN vs. GROWTH & FINANC vs. ICTPEN \\
\hline Case 1 (1961-2012) & FINANC $\leftrightarrow$ GROWTH & TELLIN $\leftarrow$ GROWTH & FINANC $\leftrightarrow$ TELLIN \\
\hline Case 2 (1991-2012) & FINANC $\leftrightarrow$ GROWTH & MOBILE $\leftarrow$ GROWTH & FINANC $\leftrightarrow$ MOBILE \\
\hline Case 3 (1991-2012) & FINANC $\leftrightarrow$ GROWTH & INTUSE $\leftrightarrow$ GROWTH & FINANC $\leftrightarrow$ INTUSE \\
\hline Case 4 (2001-2012) & FINANC $\leftrightarrow$ GROWTH & INTSER $\leftrightarrow$ GROWTH & FINANC $\leftarrow$ INTSER \\
\hline Case 5 (2001-2012) & FINANC $\leftrightarrow$ GROWTH & FIXBRO $\leftrightarrow$ GROWTH & FINANC $\rightarrow$ FIXBRO \\
\hline Case $6(2001-2012)$ & FINANC $\leftrightarrow$ GROWTH & ICTPEN $\leftrightarrow$ GROWTH & FINANC $\leftrightarrow$ ICTPEN \\
\hline
\end{tabular}

Note 1: GROWTH: per capita economic growth; FINANC: financial development; TELLIN; telephone lines penetration; MOBILE: mobile phone penetration; INTUSE: internet user penetration; INTSERV: internet server penetration; FIXBRO: fixed broadband penetration; and ICTIND: composite index of ICT penetration.

Note $2: \rightarrow$ or $\leftarrow$ : unidirectional causality in one direction or another; $\leftrightarrow$ : bidirectional causality.
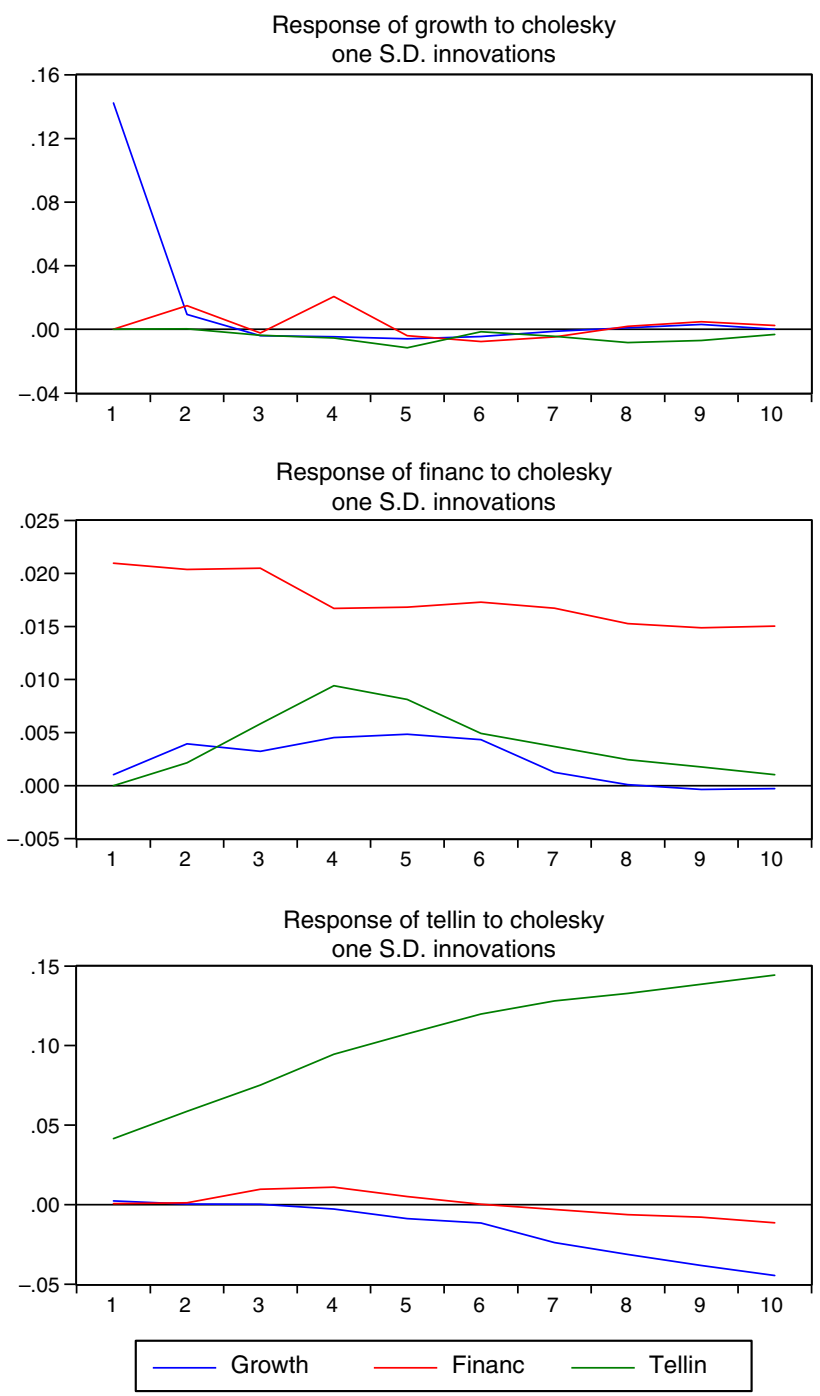

Figure 2 Response of variables to a shock when considering the relationship between economic growth, financial development, and telephone line penetration. Note. GROWTH: per capita economic growth; FINANC: financial development; and TELLIN; telephone lines penetration.
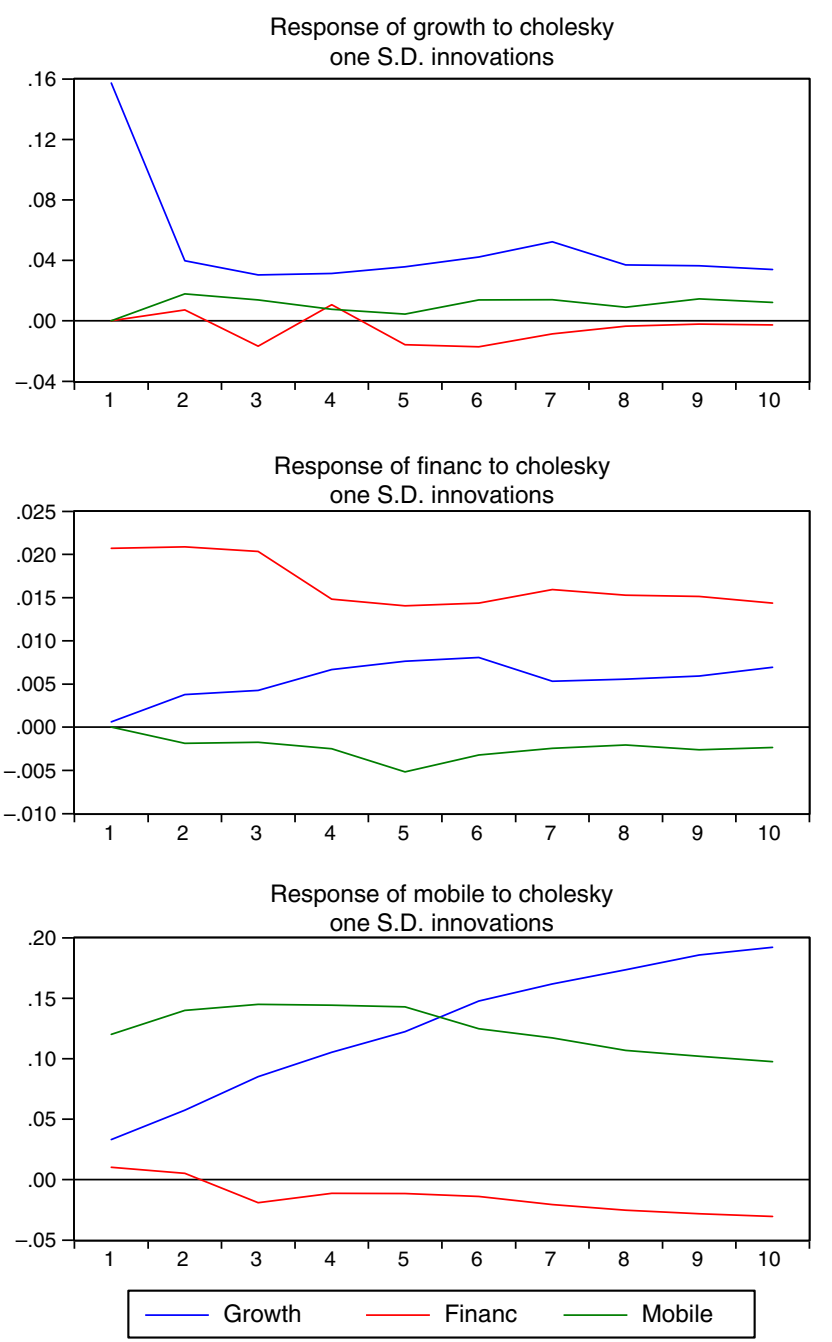

Figure 3 Response of variables to a shock when considering the relationship between economic growth, financial development, and mobile phone penetration. Note. GROWTH: per capita economic growth; FINANC: financial development; and MOBILE: mobile phone penetration. 

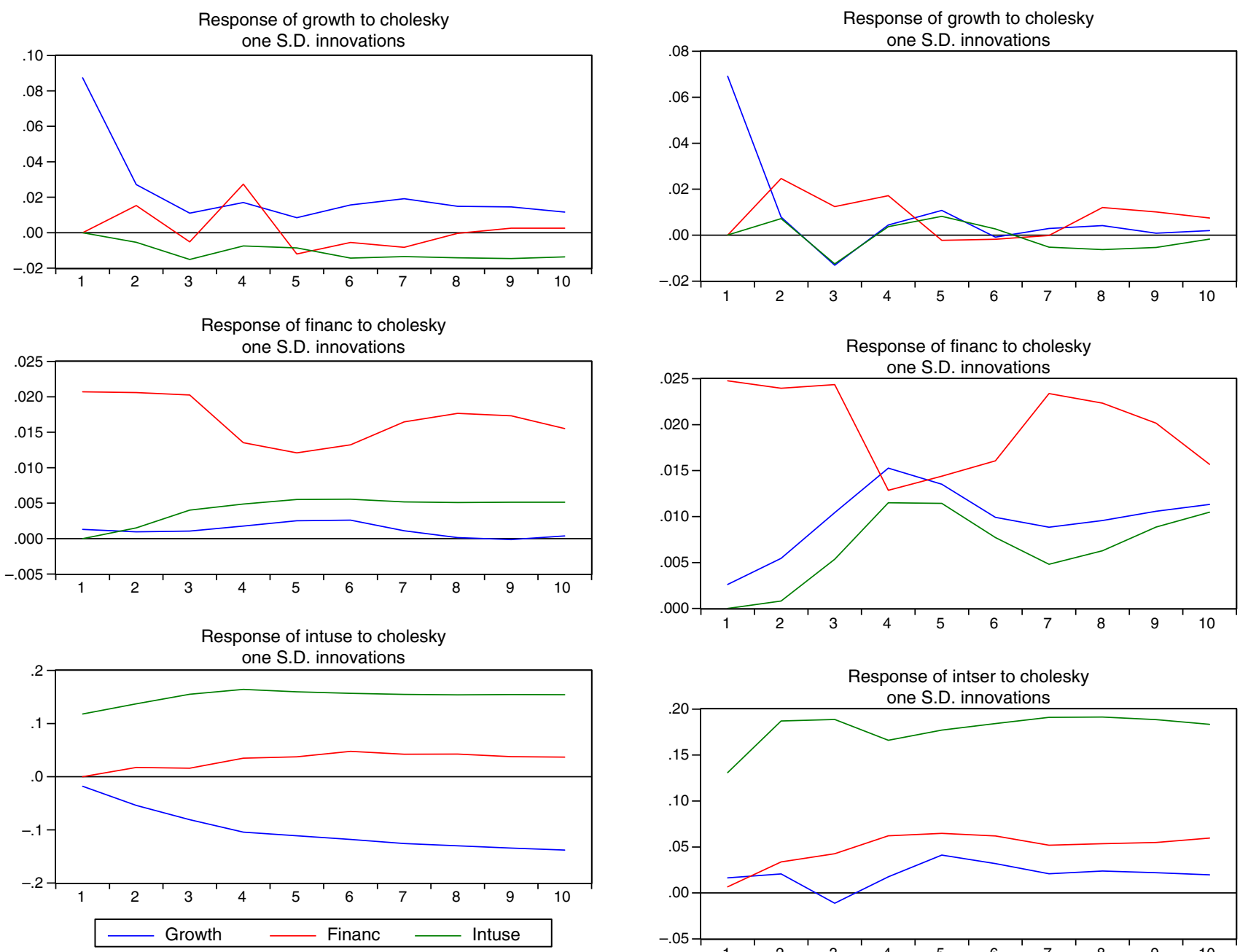

Figure 4 Response of variables to a shock when considering the relationship between economic growth, financial development, and internet user penetration. Note. GROWTH: per capita economic growth; FINANC: financial development; and INTUSE: internet user penetration.

INTUSE and GROWTH, INTSER and GROWTH, FIXBRO and GROWTH and ICTPEN and GROWTH (see Table 8, Cases 3-8). This supports the feedback hypothesis of ICT-growth nexus and is congruent with the findings of Arvin and Pradhan (2014), Chakraborty and Nandi (2009, 2011), Cronin et al. (1991), Lam and Shiu (2010), Pradhan et al. (2013b), Shiu and Lam (2008a, b), Wolde-Rufael (2007), and Zahra et al. (2008) for the various regions and countries that they study.

In addition, the study finds unidirectional causality between TELLIN and GROWTH and MOBILE and GROWTH (see Table 8, Cases 1-2). This supports the demand-following hypothesis of ICT-growth nexus and is consistent with the findings of Beil et al. (2005), Lee et al. (2012), Pradhan et al. (2013b), and Shiu and Lam (2008a,b) for the various regions and countries that they study.

The above analysis suggests that as income levels increase, the demand for all the ICTs will be on an upward trend. The empirical results also show that ICTs that provide ubiquitous high speed connectivity tend to provide a more effective platform for economic agents to pursue economies of scale and scope. This will result in improved economic

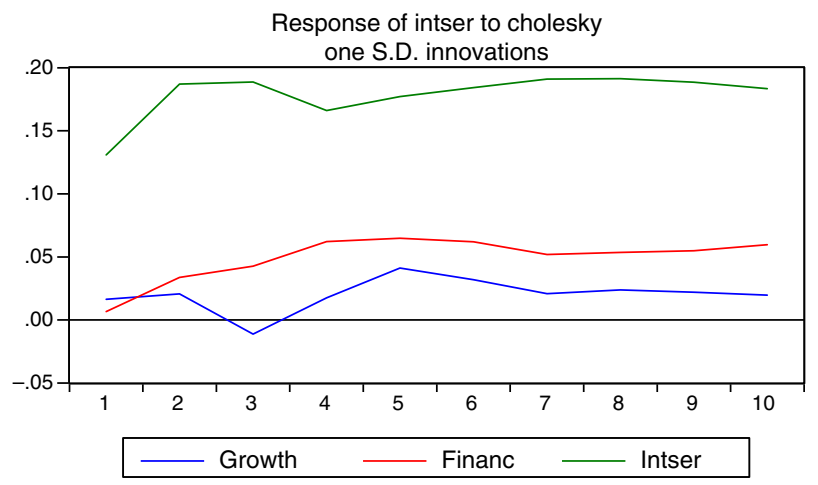

Figure 5 Response of variables to a shock when considering the relationship between economic growth, financial development, and internet server penetration. Note. GROWTH: per capita economic growth; FINANC: financial development; and INTSERV: internet server penetration.

productivity and economic growth, thus supporting the feedback hypothesis.

\subsection{3 . Dynamics between ICT penetration and financial development}

The empirical evidence suggests both bidirectional and unidirectional causality between ICT penetration and financial development. Bidirectional causality is visible between FINANC and TELLIN, FINANC and MOBILE, FINANC and INTUSE and FINANC and ICTPEN (see Table 8, Cases 1-3 \& Case 6). This supports the feedback hypothesis of ICT penetrationfinancial development nexus and is consistent with the findings of Pandey (2014).

In addition, the study also finds unidirectional causality between FINANC and INTSER and FINANC and FIXBRO (see Table 8, Cases 4-5). This supports both the demand-following hypothesis of ICT penetrationfinancial development nexus (INTSER $\Rightarrow$ FINANC) and the 

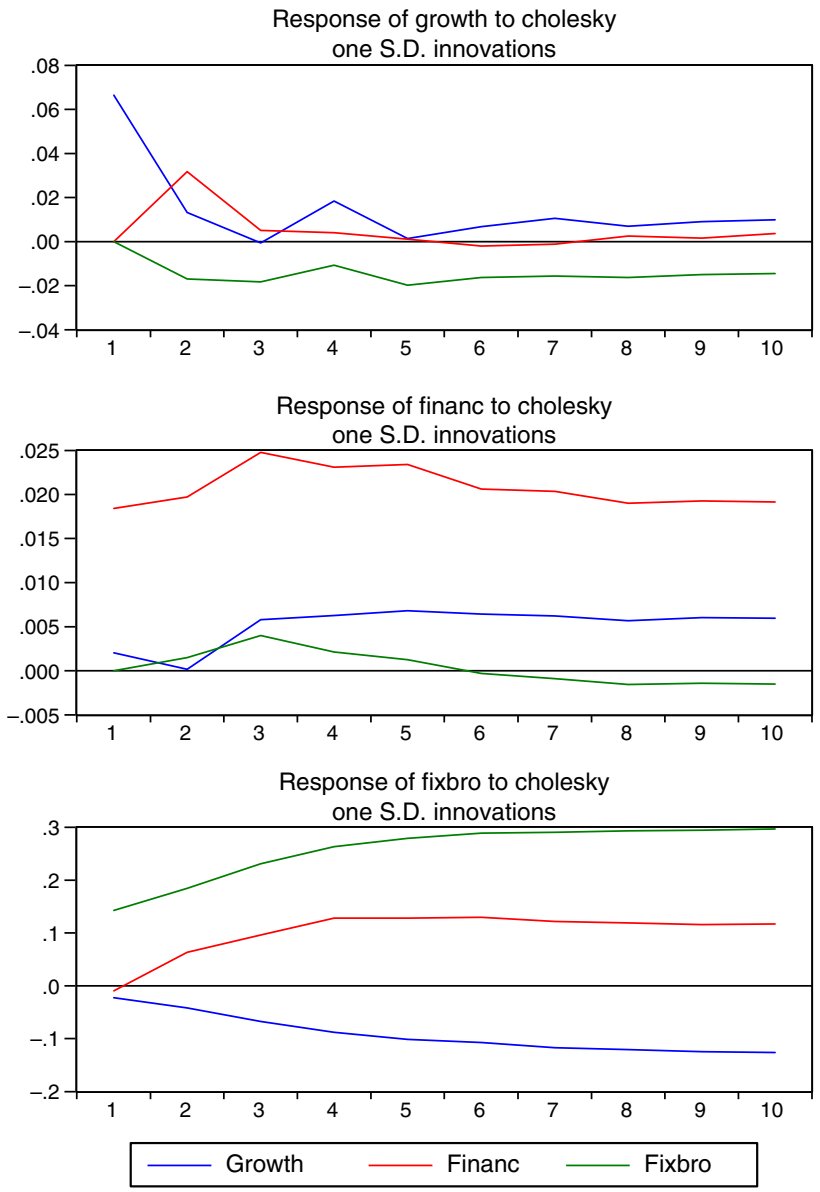

Figure 6 Response of variables to a shock when considering the relationship between economic growth, financial development, and fixed broadband penetration. Note. GROWTH: per capita economic growth; FINANC: financial development; and FIXBRO: fixed broadband penetration.

supply-leading hypothesis of ICT penetration-financial development nexus (FIXBRO $\Leftarrow$ FINANC). These results are congruent with the findings of Pandey (2014).

\subsection{Assessing shocks using generalized impulse response functions}

The generalized impulse response functions (GIRFs) approach is used to trace the effect of a one-off shock to one of the data series on the current and future values of the series. The GIRFs can also be used to summarize the direction of causal patterns in a cointegrated system and to justify the strength of the causal relationships among these variables (Riezman et al., 1996). In this context, we will examine the impact of shocks to ICT penetration and financial development onto economic growth. This analysis provides additional support for the finding that there is demonstrated causality among a subset of variables in our vector error-correction model. The results of these GRIFs are graphed in Figs. 2-7. Our discussion of the impulse response functions mainly centers on the responses of ICT penetration, financial development and per capita economic growth to their own and other shocks.
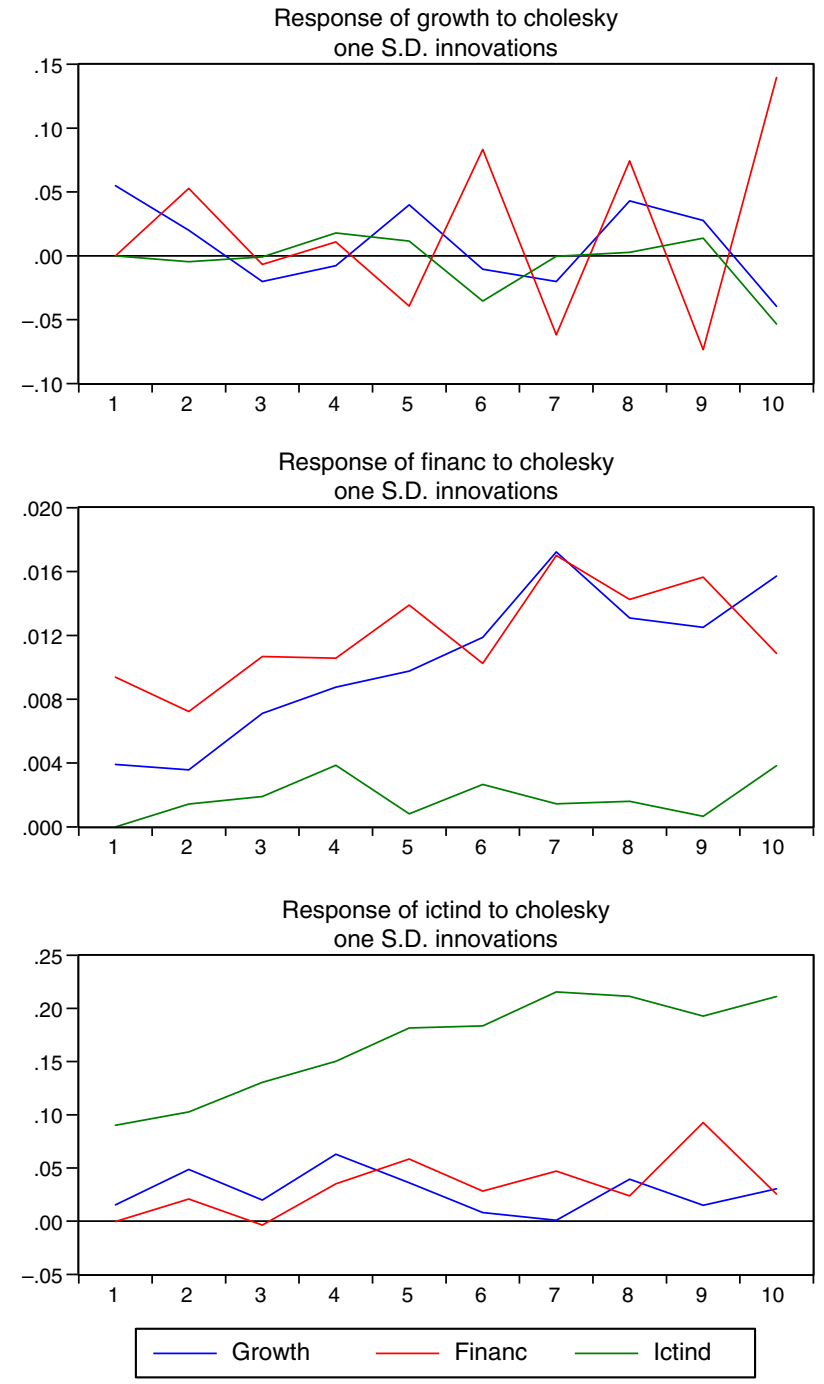

Figure 7 Response of variables to a shock when considering the relationship between economic growth, financial development, and the composite index of ICT penetration. Note. GROWTH: per capita economic growth; FINANC: financial development; and ICTIND: composite index of ICT penetration.

\section{Policy implications and conclusion}

The paper examined the short-term and long-term dynamics between ICT penetration rates, financial sector development and economic growth for 11 countries over 6 sample time periods. The causal relationships between ICT penetration and economic growth in the short run vary depending on the types of ICTs. The more sophisticated ICTs, such as internet uses, internet servers and fixed broadband, seem to support the feedback hypothesis, while the traditional ICTs, such as telephone lines and mobile phones, are impacted by economic growth. In the case of the causal relationship between financial development and economic growth, the empirical analysis shows that they reinforce one another.

Similar results were obtained for ICT (telephone line penetration, mobile phone and internet use) and financial sector development. However, internet server penetration was found to have a significant impact on financial 
sector development and not vice versa. This is not surprising as many of the new financial instruments and services are highly dependent on internet services. On the other hand, increasing financial sector development seems to increase the demand for higher speed internet, hence financial sector development was found to impact fixed broadband penetration.

The study also found that there is a long-run relationship between the different types of ICT penetration (telephone line penetration, mobile phone penetration, internet use penetration, internet server penetration, fixed broadband penetration and the composite ICT indicator), financial development and economic growth. The empirical analysis shows that causality relationships are from ICT penetration and financial sector development to economic growth.

The empirical analysis suggests that there is a close linkage between ICT penetration and financial sector development, with one reinforcing the other. As both the financial and ICT sectors become increasingly integrated, this will result in more sophisticated, user-friendly and value-creating financial products and services. This, in turn, will increase the reach of new financial services to a wider segment of the population, resulting in higher economic growth. Hence, to ensure long-term economic growth, there should be adequate investments and incentives to develop viable electronic financial ecosystems that reinforce greater ICT penetration rates and enhance wealth creation opportunities for all economic agents. Among the key investments and incentives include the following:

- Adequate investment for ICT infrastructure development, including expanding network coverage to rural and remote communities;

- Subsidies and tax-incentives to ensure ICT services are affordable for disadvantaged communities;
- Access to ICT literacy and electronic training programs that will enable all segments of the population to use the digital platform to access electronic financial services and other e-services to improve their socioeconomic wellbeing; and

- Development of a sound regulatory environment that ensures good governance of the digital platform to prevent market failures such as cybercrimes and other online criminal activities that hinder investor and user confidence.

In summary, the global economic landscape is undergoing rapid transformation powered by new innovations in the ICT and financial sectors. Increasing integration of ICT platforms and financial services is having a deeper impact on long-term economic growth of countries. For these reasons, development plans should include strategies to increase ICT penetration rates and development of modern electronic financial systems that can have a greater multiplier impact on national economic wealth. Effective policy measures that ensure sustainable economic development have been introduced in the hope of advancing the reinforcement of ICT penetration and financial sector development.

\section{Acknowledgment}

The constructive suggestions from a referee of this journal are gratefully acknowledged.

\section{Appendix A. Definition of variables}

Tables A. 1 and A.2

Table A.1 Definition of financial development variables.

\begin{tabular}{ll}
\hline Variables & Definition \\
\hline FINANC & $\begin{array}{l}\text { Composite index of financial development: based on nine financial development indicators: broad money } \\
\text { supply, claims on the private sector, domestic credit to the private sector, domestic credit provided by the } \\
\text { banking sector, domestic credit provided by the financial sector, market capitalization, traded stocks, } \\
\text { turnover ratio, and number of listed companies-derived through principal component analysis. }\end{array}$ \\
BMONEY & Broad money supply, expressed as a of gross domestic product. \\
CLAIMS & Claims on the private sectors, expressed as a \% of gross domestic product. \\
DCBANK & Domestic credit provided by the banking sector, expressed as a \% of gross domestic product. \\
DCPRIS & Domestic credit to the private sector, expressed as a \% of gross domestic product. \\
DCFINS & Domestic credit provided by the financial sector, expressed as a of gross domestic product. \\
SMACAP & Market capitalization, expressed as a \% change in the market capitalization of the listed companies, used \\
STMTRS & as a proxy for the evolution in the size of the stock market. \\
STMTUR & Traded stocks, expressed as a \% change in the total value of traded stocks, used as a proxy for the \\
NLCOMP & Turnover ratio, expressed as a \% change in the turnover ratio in the stock market, used as a proxy for the \\
& evolution in stock market turnover.
\end{tabular}

Note 1: All monetary measures are in real US dollars.

Note 2: The variables are chosen on the basis of data availability in the chosen Next-11 countries. Additionally, these nine variables are popular measures of financial development, particularly with reference to both banking sector development and stock markets development.

Note 3: See Pradhan et al. (2014c,d) and WDI for more details about these variables. 
Table A.2 Definition of ICT penetration and growth variables.

\begin{tabular}{ll}
\hline Variables & Definition \\
\hline ICTIND & $\begin{array}{l}\text { Composite index of ICT penetration: based on a composite index derived - using principal component } \\
\text { analysis and five individual ICT indicators: telephone line penetration, mobile phone penetration, internet } \\
\text { user penetration, internet server penetration, and fixed broadband penetration }\end{array}$ \\
TELLIN & Telephone line penetration: telephone landlines per thousand of population. \\
MOBILE & Mobile phone penetration: mobile phone subscribers per thousand of population. \\
INTUSE & Internet user penetration: internet users per thousand of population. \\
INTSER & Internet server penetration: internet servers per thousand of population. \\
FIXBRO & Fixed broadband penetration: Fixed broadband per thousand of population. \\
GROWTH & Per capita economic growth, expressed as a \% change in per capita gross domestic product, used as an \\
& indicator of economic growth.
\end{tabular}

Note 1: ICT denotes Information Communication Technology.

Note 2: The ICT penetration variables are chosen on the basis of data availability in the chosen Next-11 countries.

Note 3: See Pradhan et al. (2014a,b) and WDI for additional information on these variables.

Table B.1 The summary of PCA-related information for ICT penetration.

\begin{tabular}{|c|c|c|c|}
\hline SI. numbers & Eigen value & Proportion variance & Cumulative \\
\hline \multicolumn{4}{|c|}{ Part A: Eigen analysis of correlation matrix } \\
\hline PCs & Eigen value & Proportion & Cumulative \\
\hline 1 & 3.69 & 0.738 & 0.738 \\
\hline 2 & 0.75 & 0.150 & 0.889 \\
\hline 3 & 0.268 & 0.054 & 0.942 \\
\hline 4 & 0.194 & 0.039 & 0.981 \\
\hline 5 & 0.095 & 0.019 & 1.000 \\
\hline
\end{tabular}

Part B: Eigen vectors (component loadings)

\begin{tabular}{llrrrr}
\hline Variables & PC1 & PC 2 & PC 3 & PC 4 & PC 5 \\
\hline TELLIN & 0.355 & -0.811 & 0.314 & -0.153 & -0.307 \\
MOBILE & 0.420 & 0.582 & 0.496 & -0.251 & -0.420 \\
INTUSE & 0.480 & 0.045 & -0.144 & 0.853 & -0.137 \\
INTSER & 0.467 & 0.038 & -0.767 & -0.416 & -0.137 \\
FIXBRO & 0.499 & 0.008 & 0.216 & -0.111 & 0.832 \\
\hline
\end{tabular}

Note 1: PCs denotes principal components.

Note 2: TELLIN: telephone line penetration; MOBILE: mobile phone penetration; INTUSE: internet user penetration; INTSER: internet server penetration; and FIXBRO: fixed broadband penetration.

\section{Appendix B. Formulation of two composite indices using principal component analysis (PCA)}

We construct a composite index of ICT penetration, hereafter denoted by 'ICTIND' and a composite index of financial development, henceforth denoted by 'FINANC'. These indices are derived through principal component analysis using the following steps ${ }^{4}$ : first, data are arranged in the same order to create an input matrix for the principal

\footnotetext{
${ }^{4} \mathrm{~A}$ weakness of PCA is that it is a non-parametric approach. The estimation method is data-driven and is not dependent on the predilections of the users. Furthermore, PCA does not take into account any a-priori knowledge, as alternative parametric algorithms do. It also deals with linear relationships between the variables. Not surprisingly and evidently, PCA has limitations - just
}

components, thereafter the matrix is normalized, based on the min-max method. Next, using principal component analysis, eigen values, factor loadings, and principal components are derived. Finally, the principal components are used to construct the two indices separately for each country for each year. These steps are discussed in detail in several papers including Hosseini and Kaneko (2011, 2012) and Pradhan et al. (2014a, c). The variables included for the construction of the two indices are set out in Tables A.1 and A.2 (see Appendix A). The two tables (Table B.1 and Table B.2) below present the statistical values from our principal component analysis, i.e., for ICT penetration and financial development, respectively.

as every estimation procedure does - such as scaling problems, interpretation problems, and higher correlation problems. 
Table B.2 The summary of PCA-related information for financial development.

\begin{tabular}{|c|c|c|c|c|c|c|c|c|c|}
\hline \multicolumn{3}{|c|}{ Sl. numbers } & \multicolumn{2}{|l|}{ Eigen value } & \multicolumn{3}{|c|}{ Proportion variance } & \multicolumn{2}{|r|}{ Cumulative } \\
\hline \multicolumn{10}{|c|}{ Part A: Eigen analysis of correlation matrix } \\
\hline PCs & & \multicolumn{3}{|c|}{ Eigen value } & \multicolumn{2}{|c|}{ Proportion } & & \multicolumn{2}{|r|}{ Cumulative } \\
\hline 1 & & \multicolumn{2}{|r|}{5.291} & & \multicolumn{2}{|c|}{0.588} & & \multicolumn{2}{|r|}{0.588} \\
\hline 2 & & \multicolumn{2}{|r|}{1.445} & & \multicolumn{2}{|c|}{0.161} & & \multicolumn{2}{|r|}{0.784} \\
\hline 3 & & \multicolumn{2}{|r|}{1.053} & & \multicolumn{2}{|c|}{0.117} & & \multicolumn{2}{|r|}{0.865} \\
\hline 4 & & \multicolumn{2}{|r|}{0.694} & & \multicolumn{2}{|c|}{0.077} & & \multicolumn{2}{|r|}{0.942} \\
\hline 5 & & \multicolumn{2}{|r|}{0.291} & & \multicolumn{2}{|c|}{0.032} & & \multicolumn{2}{|r|}{0.975} \\
\hline 6 & & \multicolumn{2}{|r|}{0.164} & & \multicolumn{2}{|c|}{0.018} & & \multicolumn{2}{|r|}{0.993} \\
\hline 7 & & \multicolumn{2}{|r|}{0.052} & & \multicolumn{2}{|c|}{0.006} & & \multicolumn{2}{|r|}{0.998} \\
\hline 8 & & \multicolumn{2}{|r|}{0.013} & & \multicolumn{2}{|c|}{0.002} & & \multicolumn{2}{|r|}{0.999} \\
\hline 9 & & \multicolumn{2}{|r|}{0.001} & & & & & & 1.000 \\
\hline & & & Part B: & en vector & omponent & dings) & & & \\
\hline Variables & PC1 & PC 2 & PC 3 & PC4 & PC 5 & PC6 & PC7 & PC 8 & PC 9 \\
\hline BMONEY & 0.394 & 0.217 & 0.204 & -0.001 & 0.254 & 0.373 & 0.722 & -0.024 & -0.176 \\
\hline CLAIMS & 0.089 & 0.439 & -0.659 & 0.547 & -0.186 & 0.177 & -0.020 & 0.002 & -0.001 \\
\hline DCPRIS & 0.395 & 0.279 & 0.118 & 0.011 & -0.006 & -0.520 & -0.222 & -0.027 & -0.657 \\
\hline DCBANK & 0.396 & 0.284 & 0.125 & -0.009 & -0.066 & -0.467 & 0.103 & 0.009 & 0.717 \\
\hline DCFINS & 0.401 & 0.149 & 0.145 & -0.087 & 0.320 & 0.503 & -0.641 & 0.039 & 0.143 \\
\hline SMACAP & 0.219 & -0.525 & 0.152 & 0.668 & 0.193 & -0.106 & -0.001 & 0.399 & 0.013 \\
\hline STMTRS & 0.330 & -0.453 & -0.327 & -0.005 & 0.158 & -0.071 & 0.012 & -0.740 & 0.029 \\
\hline STMTUR & 0.281 & -0.220 & -0.563 & -0.494 & 0.092 & -0.068 & 0.084 & 0.538 & -0.031 \\
\hline NLCOMP & 0.357 & -0.226 & 0.161 & -0.055 & -0.85 & 0.258 & -0.016 & 0.018 & -0.045 \\
\hline
\end{tabular}

Note 1: PCs denotes principal components.

Note 2: BMONEY: broad money supply; CLAIMS: claims on the private sector; DCPRIS: domestic credit to the private sector; DCBANK: domestic credit provided by the banking sector; DCFINS: domestic credit provided by the financial sector; SMACAP: stock market capitalization; STMTRS: stock market traded stocks; STMTUR: stock market turnover ratio; and NLCOMP: number of listed companies.

\section{Appendix C. ICT and economic growth relationships}

Fig. C.1

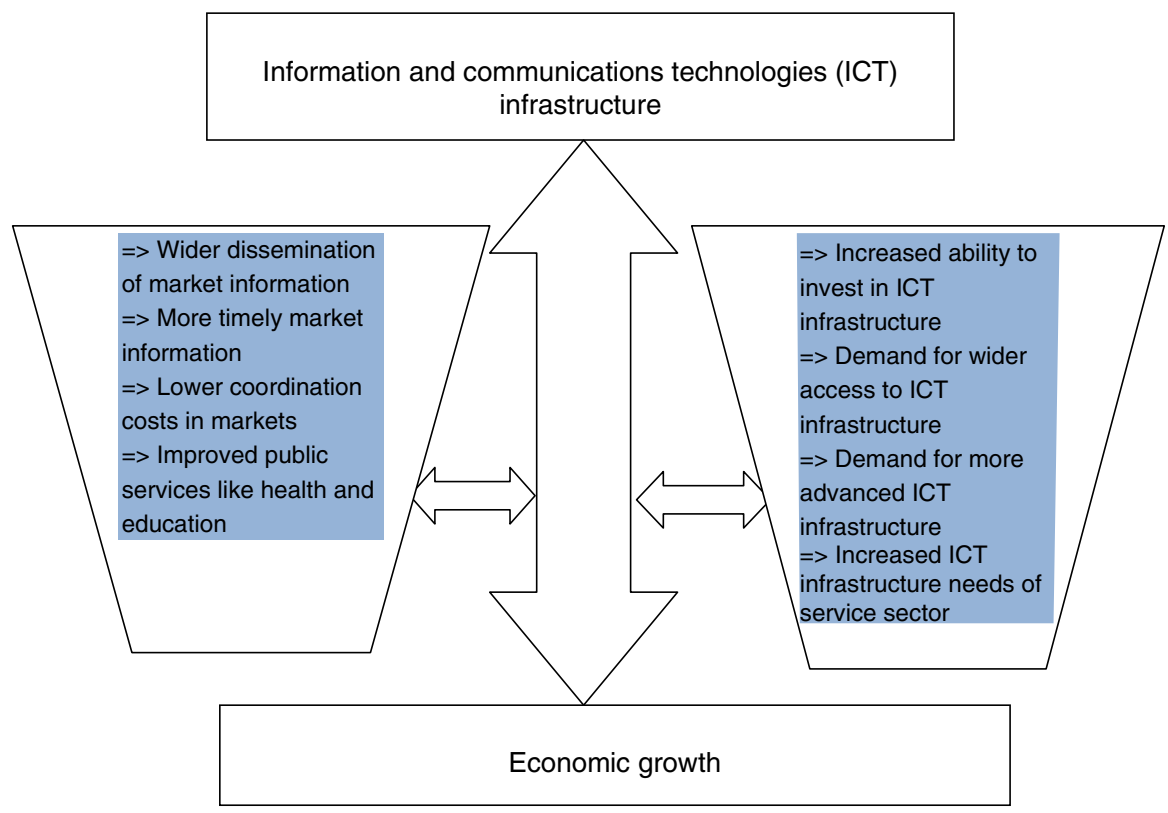

Figure C.1 Information and communications technologies (ICT) infrastructure and economic growth: the duality.

Source: Dutta (2001). 


\section{References}

Abu-Bader, Abu-Qarn, S., 2008. Financial development and economic growth: the Egyptian experience. Journal of Policy Modelling 30, 887-898.

Aghion, P., Howitt, P., 1998. Endogenous Growth Theory. MIT Press, Cambridge, MA.

Alfaro, L., Chanda, A., Kalemli-Ozcan, S., Sayek, S., 2004. FDI and economic growth: the role of local financial markets. Journal of International Economics 64, 89-112.

Andrianaivo, M., Kpodar, K., 2011. ICT, Financial Inclusion, and Growth: Evidence from African countries. IMF Working Paper, No. WP/11/73. International Monetary Fund, Washington.

Ang, J.B., 2008a. Survey of recent developments in the literature of finance and growth. Journal of Economic Surveys 22, 536-576.

Ang, J.B., 2008b. What are the mechanisms linking financial development and economic growth in Malaysia? Economic Modelling 25, 38-53.

Ang, McKibbin, J.B., 2007. Financial liberalization, financial sector development and growth: evidence from Malaysia? Journal of Development Economics 84, 215-233.

Arvin, B.M., Pradhan, R.P., 2014. Broadband penetration and economic growth nexus: evidence from cross-country panel data. Applied Economics 46, 4360-4369.

Baye, M., Morgan, J., Scholten, P., 2004. Temporal price dispersion: evidence from an online consumer electronics market. Journal of Interactive Marketing 18, 101-115.

Beil, R.O., Ford, G.S., Jackson, J.D., 2005. On the relationship between telecommunications investment and economic growth in the United States. International Economic Journal 19, 3-9.

Bhatnagar, S., 2000. Social implications of information and communication technology in developing countries: lessons from Asian success stories. Electronic Journal of Information Systems in Developing Countries 1, 1-10.

Bojanic, A.N., 2012. The impact of financial development and trade on the economic growth of Bolivia. Journal of Applied Economics 15, 51-70.

Boulila, G., Trabelsi, M., 2004. Financial development and long run growth: evidence from Tunisia: 1962-1997. Savings and Development 28, 289-314.

Brown, J., Goolsbee, A., 2002. Does the internet make markets move competitive? Evidence from the life insurance industry. Journal of Political Economy 110, 481-507.

Calderon, C., Liu, L., 2003. The direction of causality between financial development and economic growth. Journal of Development Economics 72, 321-334.

Canning, C., Pedroni, P., 2008. Infrastructure, long run economic growth and causality tests for cointegrated panels. Manchester School 76, 504-527.

Chaiechi, T., 2012. Financial development shocks and contemporaneous feedback effect on key macroeconomic indicators: a post Keynesian time series analysis. Economic Modelling 29, 487-501.

Chakraborty, C., Nandi, B., 2003. Privatization, telecommunication and growth in selected Asian countries: an econometric analysis. Communications and Strategies 52, 31-47.

Chakraborty, C., Nandi, B., 2009. Telecommunications adoption and economic growth in developing countries: do levels of development matter. Journal of Academy of Business and Economics 9, 51-61.

Chakraborty, C., Nandi, B., 2011. Mainline telecommunications infrastructure, levels of development and economic growth: evidence from a panel of developing countries. Telecommunications Policy 35, 441-449.

Chow, W.W., Fung, M.K., 2011. Financial development and growth: a clustering and causality analysis. Journal of International Trade and Economic Development 35, 1-24.
Christopoulos, D.K., Tsionas, E.G., 2004. Financial development and economic growth: evidence from panel unit root and cointegration tests. Journal of Development Economics 73, 55-74.

Cieslik, A., Kaniewsk, M., 2004. Telecommunication infrastructure and regional economic development: the case of Poland. Regional Studies 38, 713-725.

Cihak, M., Demirguc-Kunt, A., Feyen, E., Levine, R., 2011. Financial development in 205 economies, 1960-2010. Journal of Financial Perspectives 2, 17-37.

Craigwell, R., Downes, D., Howard, M., 2001. The finance-growth nexus: a multivariate VAR analysis of a small open economy. Savings and Development 25, 209-223.

Cronin, F.J., Parker, E.B., Colleran, E.K., Gold, M.A., 1991. Telecommunications infrastructure and economic growth: an analysis of causality. Telecommunications Policy 15, 529-535.

Dritsakis, N., Adamopoulos, A., 2004. Financial development and economic growth in Greece: an empirical investigation with granger causality analysis. International Economic Journal 18, 547-559.

Dutta, A., 2001. Telecommunication and economic activity: an analysis of Granger causality. Journal of Management Information Systems 17, 71-95.

Engle, R., Granger, C.W., 2003. Time series econometrics: cointegration and autoregressive conditional heteroscedasticity. In: Advanced Information on the Bank of Sweden Prize in Economic Sciences in Memory of Alfred Nobel., pp. 1-30, http://www.nobelprize.org/nobel_prizes/economic-sciences/ laureates/2003/advanced-economicsciences2003.pdf

Engle, R.F., Granger, C.W.J., 1987. Cointegration and error correction: representation, estimation and testing. Econometrica 55, 251-276.

Entner, R., 2008. The increasingly important impact of wireless broadband technology and services on the US economy, An Ovum Study for CTIA-The Wireless Association. http://files.ctia.org/ pdf/Final_OvumEconomiclmpact_Report_5_21_08.pdf (accessed 09.05.13).

Fase, M.M.G., Abma, R.C.N., 2003. Financial environment and economic growth in selected Asian countries. Journal of Asian Economics 14, 11-21.

Fitjar, R.D., Rodríguez-Pose, A., 2013. Firm collaboration and modes of innovation in Norway. Research Policy 42, 128-138.

Forman, C., Goldfarb, A., Greenstein, S., 2005. Geographic location and the diffusion of internet technology. Electronic Commerce Research and Applications 4, 1-13.

Granger, C.W., Newbold, P., 1974. Spurious regressions in econometrics. Journal of Econometrics 2, 111-120.

Greenwood, J., Jovanovic, B., 1990. Financial development, growth and the distribution of income. The Journal of Political Economy 98, 1076-1107.

Gries, T., Kraft, M., Meierrieks, D., 2009. Linkages between financial deepening, trade openness, and economic development: causality evidence from sub-Saharan Africa. World Development 37, 1849-1860.

Grossman, G.M., Helpman, E., 1994. Endogenous innovation in the theory of growth. Journal of Economic Perspectives 8, 23-44.

Holtz-Eakin, D., Newey, W., Rosen, H.S., 1988. Estimating vector auto regressions with panel data. Econometrica 56, 1371-1395.

Hosseini, H.M., Kaneko, S., 2011. Dynamics sustainability assessment of countries at the macro level: a principal component analysis. Ecological Indicators 11, 811-823.

Hosseini, H.M., Kaneko, S., 2012. Causality between pillars of sustainable development: global stylized facts or regional phenomena. Ecological Indicators 14, 197-201.

Hsueh, S., Hu, Y., Tu, C., 2013. Economic growth and financial development in Asian countries: a bootstrap panel Granger causality analysis. Economic Modelling 32, 294-301. 
Im, K.S., Pesaran, M.H., Shin, Y., 2003. Testing for unit roots in heterogeneous panels. Journal of Econometrics 115, 53-74.

Jalil, A., Feridun, M., Ma, Y., 2010. Finance-growth nexus in China revisited: new evidence from principal components and ARDL bounds tests. International Review of Economics and Finance 19, 189-195.

Kalam, A.P.J., 2003. Citizen Centric e-Governance: technology and management policy. Finance India XVII, 1273-1277.

Kao, C., Chiang, M.H., 2000. On the estimation and inference of a cointegrated regression in panel data. Advances in Econometrics: Nonstationary Panels, Panel Cointegration and Dynamic Panels 15, 179-222.

Kar, M., Nazlioglu, S., Agir, H., 2011. Financial development and economic growth nexus in the MENA countries: bootstrap panel Granger causality analysis. Economic Modelling 28 (1-2), 685-693.

King, R., Levine, R., 1993. Finance and growth: Schumpeter might be right. Quarterly Journal of Economics 108, 717-737.

Lam, P.L., Shiu, A., 2010. Economic growth, telecommunications development and productivity growth of the telecommunications sector: evidence around the world. Telecommunications Policy 34, 185-199.

Lechman, E., Marszk, A., 2015. ICT technologies and financial innovations: the case of exchange traded funds in Brazil, Japan, Mexico, South Korea and the United States. Technological Forecasting and Social Change 99, 355-376.

Lee, S.H., Levendis, J., Gutierrez, L., 2012. Telecommunications and economic growth: an empirical analysis of Sub-Saharan Africa. Applied Economics 44, 461-469.

Levine, A., Lin, C.F., Chu, C.S., 2002. Unit root tests in panel data: asymptotic and finite sample properties. Journal of Econometrics $108,1-24$.

Levine, R., Zervos, S., 1996. Stock market development and longrun growth. World Bank Economic Review 10, 323-339.

Levine, R., Loayza, N., Beck, T., 2000. Financial intermediation and growth: causality analysis and causes. Journal of Monetary Economics 46, 31-77.

Liang, Q., Teng, J., 2006. Financial development and economic growth: evidence from China. China Economic Review 17, 395-411.

Maddala, G.S., Wu, S., 1999. A comparative study of unit root tests with panel data and new simple test. Oxford Bulletin of Economics and Statistics 61 (S1), 631-652.

Maeso-Fernandez, F., Osbat, C., Schnatz, B., 2006. Towards the estimation of equilibrium exchange rates for CEE acceding countries: methodological issues and a panel cointegration perspective. Journal of Computational Economics 34, 499-517.

Mark, C.N., Sul, D., 2003. Cointegration vector estimation by panel DOLS and long-run money demand. Oxford Bulletin of Economics and Statistics 65, 655-680.

Mehmood, B., Siddiqui, W., 2013. What causes what? Panel cointegration approach on investment in telecommunication and economic growth: case of Asian countries. Romanian Economic Journal 16, 3-16.

Menyah, K., Nazlioglu, S., Wolde-Rufael, Y., 2014. Financial development, trade openness and economic growth in African countries: new insights from a panel causality approach. Economic Modelling 37, 2014.

Morck, R., Yeung, B., Yu, W., 2000. The information content of stock markets: why do emerging markets have synchronous stock price movement? Journal of Financial Economics 58, 215-260.

Mukhopadhyay, B., Pradhan, R.P., Feridun, M., 2011. Financegrowth nexus revisited for some Asian countries. Applied Economics Letters 18, 1527-1530.

Naceur, S.B., Ghazouani, S., 2007. Stock markets, banks, and economic growth: empirical evidence from the MENA region. Research in International Business and Finance 21, 297-315.
Nair, M., 2011. Inclusive innovation and sustainable development: leap-frogging strategies to a high income economy. In: Ramasamy, R. (Ed.), ICT Strategic Review 2011/2012. PIKOM and MOSTI, Malaysia, pp. 225-257 (Chapter 11).

Nair, M. Shariffadeen, T.M.A., 2009. Managing innovation in the network economy: lessons for countries in the Asia-Pacific region. Digital Review of Asia Pacific 2009-2010, 25-42.

Nair, M., Vaithilingam, S., 2012. Innovative use of ICT among urbanpoor communities: challenges and opportunities. In: Ramasamy, R. (Ed.), ICT Strategic Review 2012/2013. PIKOM and MOSTI, Malaysia, pp. 181-191.

Odhiambo, N.M., 2008. Financial development in Kenya: a dynamic test of the finance-led growth hypotheses. Economic Issues 13, 21-36.

Odhiambo, N.M., 2010. Finance-investment-growth nexus in South Africa: an ARDL bounds testing procedure. Economic Change Restructuring 43, 205-219.

Omri, A., Daly, S., Rault, C., Chaibi, A., 2015. Financial development, environmental quality, trade and economic growth: what causes what in MENA countries? Energy Economics 48, 242-252.

Pandey, S.K., (Ph.D. thesis) 2014. ICT Diffusion, Financial Development and Economic Growth: The Causal Nexus in Selected Asian Countries. Indian Institute of Technology, Kharagpur.

Panopoulou, E., 2009. Financial variables and euro area growth: a non-parametric causality analysis. Economic Modelling 26, 1414-1419.

Patrick, H.T., 1966. Financial development and economic growth in underdeveloped countries. Economic Development and Cultural Change 14, 174-189.

Pedroni, P., 2004. Panel cointegration: asymptotic and finite sample properties of pooled time series tests, with an application to the PPP hypothesis. Econometric Theory 20, 597-625.

Pedroni, P., 2000. Fully modified OLS for heterogeneous cointegrated panels. Advanced in Econometrics 15, 93-130.

Pedroni, P., 2001. Purchasing power parity tests in cointegrated panels. Review of Economics and Statistics 83, 727-731.

Pradhan, R.P., Arvin, M.B., Norman, N.R., 2015. The dynamics of information and communications technologies infrastructure, economic growth, and financial development: Evidence from Asian countries. Technology in Society 42, 135-149.

Pradhan, R.P., Arvin, M.B., Norman, N.R., Bele, S.K., 2014a. Economic growth and the development of telecommunications infrastructure in the G-20 countries: a panel-VAR approach. Telecommunications Policy 38, 634-649.

Pradhan, R.P., Arvin, M.B., Bahmani, S., Norman, N.R., 2014b. Telecommunications infrastructure and economic growth: comparative policy analysis for the G-20 developed and developing countries. Journal of Comparative Policy Analysis 16, 401-423.

Pradhan, R.P., Arvin, M.B., Norman, N.R., Hall, J.H., 2014c. Causal nexus between economic growth, banking sector development, stock market development and other macroeconomic variables: the case of ASEAN countries. Review of Financial Economics 23, $155-173$.

Pradhan, R.P., Arvin, M.B., Norman, N.R., Hall, J.H., 2014d. The dynamics of banking sector and stock market maturity and the performance of Asian economies. Journal of Economic and Administrative Sciences 30, 16-44.

Pradhan, R.P., Bele, S., Pandey, S., 2013a. Internet-growth nexus: evidence from cross country panel data. Applied Economics Letters 20, 1511-1515.

Pradhan, R.P., Bele, S., Pandey, S., 2013b. The Link between telecommunication infrastructure and economic growth in 34 OECD countries. International Journal of Technology, Policy and Management 13, 278-293.

Pradhan, R.P., Mukhopadhyay, B., Gunashekar, A., Bele, S., Pandey, S., 2013c. Financial development, social development, and economic growth: the causal nexus in Asia. Decision 40 (1-2), 69-83. 
Quibria, M.G., Tschang, T., Reyes-Macasaquit, M.-L., 2002. New Information and Communication Technologies and Poverty: some evidence from developing Asia. Journal of the Asia Pacific Economy 7, 285-309.

Ramlan, J., Ahmed, E.M., 2009. Information and communication technology (ICT) and human capital management trend in Malaysia's economic development. Applied Economics Letters 16, 1881-1886.

Riezman, R.G., Summers, P.M., Whiteman, C.H., 1996. The engine of growth or its handmiden? A time series assessment of exportled growth. Empirical Economics 21, 77-113.

Roller, L., Waverman, L., 2001. Telecommunications infrastructure and economic development: a simultaneous approach. American Economic Review 91, 909-923.

Romer, P.M., 1986. Increasing returns and long run growth. Journal of Political Economy 94, 1024-1037.

Sadun, R., Farooqui, S., 2006. Broadband availability, use and impact on returns to ICT in UK firms. In: OECD Working Party on Indicators for the Information Society, 3-4 May, 2006, OECD, Paris.

Sassi, S., Goaied, M., 2013. Financial development, ICT diffusion and economic growth: lessons from MENA region. Telecommunications Policy 37 (4-5), 252-261.

Schumpeter, P., 1934. The Theory of Economic Development. Harvard University Press, Cambridge.

Shamim, F., 2007. The ICT environment, financial sector and economic growth: a cross-country analysis. Journal of Economic Studies 34, 352-370.

Shiu, A., Lam, P.L., 2008a. Causal relationship between telecommunication and economic growth in China and its regions. Regional Studies 42, 705-718.

Shiu, A., Lam, P.L., 2008b. Causal relationship between telecommunication and economic growth: a study of 105 countries. In: 17th Biennial Conference of the International Telecommunications Society (ITS), June, Montreal, pp. 24-27.

Solow, R.M., 1956. A contribution to the theory of economic growth. Quarterly Journal of Economics 70, 65-94.

Tang, Z., Smith, M.D., Montgomery, A., 2007. The impact of shopbot use on prices and price dispersion: evidence from online book retailing. Heinz Research, Paper 47 http:// repository.cmu.edu/heinzworks/47 (accessed 09.05.13).

Uddin, G.S., Shahbaz, M., Arouri, M., Teulon, F., 2014. Financial Development and Poverty Reduction Nexus: a cointegration and causality Analysis in Bangladesh. Economic Modelling 36, 405-412.

Ulgen, F., 2015. Schumpeterian innovations, financial innovations and instability: An institutional perspective. Cuadernos de Economía 38, 46-53.

Veeramacheneni, B., Ekanayake, E.M., Vogel, R., 2007. Information technology and economic growth: a causal analysis. Southwestern Economic Review 34, 75-88.

Wolde-Rufael, Y., 2007. Another look at the relationship between telecommunications investment and economic activity in the United States. International Economic Journal 21, 199-205.

Wolde-Rufael, Y., 2009. Re-examining the financial development and economic growth nexus in Kenya. Economic Modelling 26, $1140-1146$.

Wu, J., Hou, H., Cheng, S., 2010. The dynamic impacts of financial institutions on economic growth: evidence from the European Union. Journal of Macroeconomics 32, 879-891.

Yoo, S.H., Kwak, S.J., 2004. Information technology and economic development in Korea: a causality study. International Journal of Technology Management 27, 57-67.

Zahra, K., Azim, P., Mahmood, A., 2008. Telecommunications infrastructure development and economic growth: a panel data approach. Pakistan Development Review 47, 711-726. 